\title{
ENVIRONMENTAL CHARACTERIZATION AND SPATIAL DISTRIBUTION OF FISH FAUNA IN ESTUARIES IN THE STATE OF PERNAMBUCO, BRAZIL
}

\author{
Andréa Carla Guimarães de PAIVA ${ }^{1}$ \\ Maria Elisabeth de ARAújo ${ }^{2}$ \\ ${ }^{1}$ Researcher of Program for Scientific \\ Regional, University Federal of Alagoas \\ (UFAL) - CNPq/FAPEAL (research grant). E- \\ mail: acg paiva@hotmail.com
${ }^{2}$ Associate Professor II, Oceanography Dept. - University Federal of Pernambuco (UFPE). E-mail: elisabeth.araujo@ufpe.br

Recebido em: 24/11/09

Aceito em: 05/01/10

\section{RESUMO}

O presente estudo teve como objetivos identificar e caracterizar os principais fatores fisiográficos das áreas estuarinas em Pernambuco, assim como as ações antrópicas por elas sofridas; listar os peixes que vivem nesses estuários, atualizando as validações dos nomes científicos das espécies; e analisar a distribuição dos registros de ocorrência das espécies por estuário. Os dados para a análise dos estuários foram baseados em três trabalhos sobre áreas estuarinas em Pernambuco. As informações sobre a ictiofauna foram obtidas a partir de 25 monografias, dissertações, teses, livros e artigos científicos. Foram utilizadas imagens das áreas estuarinas obtidas através do aplicativo Google earth. Foram identificados 17 estuários em Pernambuco, onde a ictiofauna é pouco estudada. As maiores concentrações das pesquisas ocorreram no complexo estuarino de Itamaracá e no estuário do rio Formoso, porém para algumas áreas não existem informações sobre comunidade de peixes. Foram listadas 202 espécies de peixes válidas, sendo 52,5\% delas associadas a recifes. Quanto à freqüência de ocorrência, Citharichthys spilopterus e Poecilia vivipara foram classificadas como muito freqüentes, enquanto Carangidae, Gerreidae, Ariidae e Haemulidae foram as famílias mais especiosas. Atualmente, as áreas estuarinas estão em acelerado processo de degradação devido aos aterros, despejos de esgotos domésticos e industriais, desenvolvimento urbano, viveiros de carcinicultura e construção/ampliação de portos em prol do crescimento econômico. Diante desse contexto, torna-se necessário que os órgãos de fomento à pesquisa em Pernambuco estimulem estudos nessas áreas para possibilitar uma pesca sustentável.

Palavras-chave: Comunidade de peixes, áreas estuarinas, impactos ambientais. 
PAIVA, C. G. de; ARAUJO, M. E. de . Environmental characterization and spatial distribution of fish fauna in estuaries in the State of Pernambuco, Brazil.

\begin{abstract}
The aim of the present study was to gather data on estuaries in the state of Pernambuco and their fish fauna, identifying and characterizing the main physiographic traits of estuarine areas. Further aims were to study the anthropogenic influence over the estuaries, list the fish species (updating their scientific names) and analyze the distribution of species by estuary. The data for the analysis of the estuaries were based on three studies of estuarine areas in Pernambuco. Information on the fish fauna were obtained from 25 monographs, dissertations, theses, books and scientific articles. The images used were obtained from estuarine areas through the Google earth. Seventeen estuaries were identified in Pernambuco; there were few studies on the fish fauna of these estuaries. The largest number of studies addressed the estuarine environment of Itamaracá and Rio Formoso. No data on fish communities were found for some locations. Two hundred two valid species were listed, 52.5\% were associated to reefs. Citharichthys spilopterus and Poecilia vivipara were classified as very frequent. Carangidae, Gerreidae, Ariidae and Haemulidae were the most species-rich families. Estuarine areas are currently suffering intense degradation mainly due to landfills, domestic and industrial sewage, urban development, shrimp farms and harbor construction or amplification for the economic growth. It is necessary for fostering agencies to encourage further studies in these areas to allow sustainable fisheries.
\end{abstract}

Keywords: Fish community, Estuarine areas, Environmental impact

\title{
INTRODUCTION
}

The state of Pernambuco (northeastern Brazil) has $187 \mathrm{Km}$ of coastline extending from the city of Goiana, on the border with the state of Paraíba, to the city of São José da Coroa Grande on the border with the state of Alagoas (FIDEM, 1987). Mangroves occupy approximately 25,000 hectares and are distributed throughout 14 estuaries (Lira et al., 1992).

Estuaries are semi-closed bodies of coastal water connected to the open sea, within which seawater is measurably diluted with the freshwater draining from the land (Pritchard, 1967). The term estuary is generically used to indicate the place where river and sea meet, characterizing a coastal delta and a transition environment of between the ocean and land (Miranda et al., 2002).

Fish in estuarine systems represent approximately $99 \%$ of the nektonic species (Araújo et al., 2004) and play an important ecological role by conducting energy from lower to upper levels of the food chain, exchanging energy with neighboring ecosystems and/or storing energy through species that penetrate the estuaries and spend a large part of their lives in these environments (Yánez-Arancíbia, 1978; Blaber, 2000). Estuaries have considerable ecological importance to fish communities as 
areas of protection for juveniles and refuge for some breeding adults and offer a considerable availability of food sources (Blaber, 2000).

The fish populations that dominate estuaries are made up of juvenile marine migrant species (Rozas \& Zimmerman, 2000; Vidy, 2000), with few resident or occasional visiting species (Caberty et al., 2004). It is estimated that $20 \%$ of the total number of marine species migrate constantly to the estuarine systems (Haimovici \& Klippel, 1999). There is a high occurrence in estuaries of migrant marine species associated to reefs (Ferreira et al., 2004). Five hundred twenty-two species of marine fish in Brazil are reported to be associated to reefs (Carvalho-Filho et al., 2005) and many of these species occur in estuaries, corresponding to more than $50 \%$ of the total number of species in the estuary of the Formoso River in the state of Pernambuco (Paiva et al., 2009).

Estuarine fish communities may vary according to rainfall patterns, shape of the estuary, tide dynamics, water transparency, quality and type of organic matter, speed of the current and availability of food sources (Camargo \& Isaac, 2003).

In the state of Pernambuco, the majority of studies on estuaries are restricted to theses, dissertations, monographs, abstracts and technical reports. The aim of the present study was to compile existing information on fish fauna in the estuaries of Pernambuco in order to (1) identify and characterize the main physiographic factors of the estuarine areas and the influence of human actions; (2) list the fish that live in these estuaries, updating the validations of the scientific names of the species; and (3) analyze the distribution of the records of occurrence of the species by estuary.

\section{MATERIALS AND METHODS}

The physiographic characteristics of the estuaries of Pernambuco were based on studies carried out by FIDEM (Recife Municipal Development Foundation, 1987), CPRH (Pernambuco Environmental and Water Resources Agency, 2009a; 2009b) and Macêdo et al., (2004). Images obtained from Google Earth (2009) were used for the localization of these estuaries. Data were compiled from 21 papers (scientific articles, book chapters, monographs, dissertations and theses) addressing estuarine fish assemblages or lists of species for the analysis of the spatial distribution of the fish fauna (Table I).

The revision carried out for the taxonomic validation of the scientific names of the species was based on the studies by Menezes et al. (2003); Reis et al. (2003); Araújo et al. (2004); Fisher et al. (2004); Nelson (2006); Ferraris (2007); Marceniuk \& Menezes (2007); Eschmeyer (2008); Froese \& Pauly (2008) and the aim of which was to update the names of species considered incorrect or synonymous. 
PAIVA, C. G. de; ARAUJO, M. E. de . Environmental characterization and spatial distribution of fish fauna in estuaries in the State of Pernambuco, Brazil.

For each species listed, its possible dependence on reef environments and frequency of occurrence of species in the estuaries of Pernambuco. The studies by Humann \& Deloach (2002) and Ferreira et al. (1995) were the main sources for the determination of reef-associated species.

Frequency of occurrence (FO) was calculated by the ratio between the number of times a given species occurred in each estuary and the total number of estuaries analyzed. Species were classified as rare $(0>\mathrm{FO} \% \leq 11)$; infrequent $(11>\mathrm{FO} \% \leq 44)$; frequent $(44>\mathrm{FO} \% \leq 66)$; and very frequent $(66>\mathrm{FO} \% \leq 100)$. 
Table I - Estuaries analyzed, with respective geographic coordinates and bibliographic references addressing estuarine fish fauna

\begin{tabular}{|c|c|c|c|}
\hline No & ESTUARIES & COORDINATES & REFERENCES \\
\hline 1 & Goiana and Megaó Rivers & $\begin{array}{l}7032^{\prime}, 7035^{\prime} \mathrm{S} \text { and } 34^{\circ} 50^{\prime}, \\
34^{\circ} 58^{\prime} \mathrm{W}\end{array}$ & Oliveira (1979); Dantas (2008). \\
\hline 2 & Itapessoca River & $7041^{\prime} \mathrm{S}$ and $34^{\circ} 50^{\prime} \mathrm{W}$ & Falcão (2007); Souza (2003). \\
\hline 3 & Jaguaribe River & $7043^{\prime} \mathrm{S}$ and $34^{\circ} 49^{\prime} \mathrm{W}$ & Oliveira (1979); El-Deir (2005). \\
\hline 4 & Itamaracá Estuary Complex & $\begin{array}{l}7034^{\prime} 00^{\prime \prime}, 7055^{\prime} 16^{\prime \prime} \mathrm{S} \text { and } \\
34^{\circ} 48^{\prime} 48^{\prime \prime}, 34^{\circ} 52^{\prime} 24^{\prime \prime} \mathrm{W}\end{array}$ & $\begin{array}{l}\text { Eskinazi (1967/69); Eskinazi (1972); Oliveira } \\
\text { (1979); Azevedo \& Guedes (1980); } \\
\text { Vasconcelos-Filho et al. (1994); Almeida et al. } \\
\text { (1997); Almeida et al. (1998); Cavalcanti et } \\
\text { al. (1998); Teixeira \& Campos (2000); } \\
\text { Vasconcelos-Filho et al. (1994/1995); } \\
\text { Vasconcelos-Filho \& Oliveira (2000); } \\
\text { Vasconcelos-Filho (2001). }\end{array}$ \\
\hline 5 & Timbó River & $7050^{\prime} \mathrm{S}$ and $34^{\circ} 50^{\prime} \mathrm{W}$ & Oliveira (1979). \\
\hline 6 & Paratibe River & $7057^{\prime} \mathrm{S}$ and $34^{\circ} 49^{\prime} \mathrm{W}$ & No information available in the literature \\
\hline 7 & Beberibe River & $8^{\circ} 01^{\prime} \mathrm{S}$ and $34^{\circ} 51^{\prime} \mathrm{W}$ & Oliveira (1979). \\
\hline 8 & Capibaribe River & $8^{\circ} 02^{\prime} \mathrm{S}$ and $34^{\circ} 51^{\prime} \mathrm{W}$ & Oliveira (1979). \\
\hline 9 & $\begin{array}{l}\text { Jaboatão and Pirapama } \\
\text { Rivers }\end{array}$ & $8^{\circ} 13^{\prime} \mathrm{S}$ and $34^{\circ} 55^{\prime} \mathrm{W}$ & Oliveira (1979). \\
\hline 10 & Suape Estuary Complex & $\begin{array}{l}8^{\circ} 23^{\prime}, 8^{\circ} 24^{\prime} \mathrm{S} \text { and } 34^{\circ} 57^{\prime}, \\
34^{\circ} 58^{\prime} \mathrm{W}\end{array}$ & $\begin{array}{l}\text { Oliveira (1979); Vasconcelos-Filho et al. } \\
\text { (1990). }\end{array}$ \\
\hline
\end{tabular}


PAIVA, C. G. de; ARAUJO, M. E. de. Environmental characterization and spatial distribution of fish fauna in estuaries in the State of Pernambuco, Brazil.

\begin{tabular}{|c|c|c|c|}
\hline No & ESTUARIES & COORDINATES & REFERENCES \\
\hline 11 & Maracaípe River & $8^{\circ} 32^{\prime} \mathrm{S}$ and $35^{\circ} 00^{\prime} \mathrm{W}$ & No information available in the literature \\
\hline 12 & Sirinhaém River & $8^{\circ} 36^{\prime} \mathrm{S}$ and $35^{\circ} 02^{\prime} \mathrm{W}$ & No information available in the literature \\
\hline 13 & Formoso River & $\begin{array}{l}8^{\circ} 37^{\prime}, 8^{\circ} 40^{\prime} \mathrm{S} \text { and } \\
35^{\circ} 04^{\prime}, 35^{\circ} 08^{\prime} \mathrm{W}\end{array}$ & $\begin{array}{l}\text { Oliveira (1979); Santos (2001); Castro } \\
\text { (2005); Medeiros (2005); Fittpaldi (2006); } \\
\text { Cardoso (2006); Lima (2007); Paiva (2007); } \\
\text { Paiva et al. (2008). }\end{array}$ \\
\hline 14 & $\begin{array}{l}\text { Ilhetas and Mamucabas } \\
\text { Rivers }\end{array}$ & $8^{\circ} 47^{\prime} \mathrm{S}$ and $35^{\circ} 06^{\prime} \mathrm{W}$ & Oliveira (1979). \\
\hline 15 & Una River & $8^{\circ} 49^{\prime} \mathrm{S}$ and $35^{\circ} 08^{\prime} \mathrm{W}$ & Oliveira (1979). \\
\hline 16 & Meireles Stream & $8^{\circ} 52^{\prime} \mathrm{S}$ and $35^{\circ} 08^{\prime} \mathrm{W}$ & No information available in the literature \\
\hline 17 & Persinunga River & $8^{\circ} 54^{\prime} \mathrm{S}$ and $35^{\circ} 09^{\prime} \mathrm{W}$ & No information available in the literature \\
\hline
\end{tabular}




\section{RESULTS}

The physiographic factors of the estuaries of Pernambuco, based on descriptions from FIDEM (1987) and CPRH (2009) are displayed in Appendix 1. Comparing the information from FIDEM (1987) with the current images obtained from Google Earth (2009), a review and characterization of the estuaries of Pernambuco were carried out, identifying 17 estuaries (Figure 1).

Figure 1 - Estuaries of Pernambuco based on images obtained from Google Earth (2009), arranged from North to South.

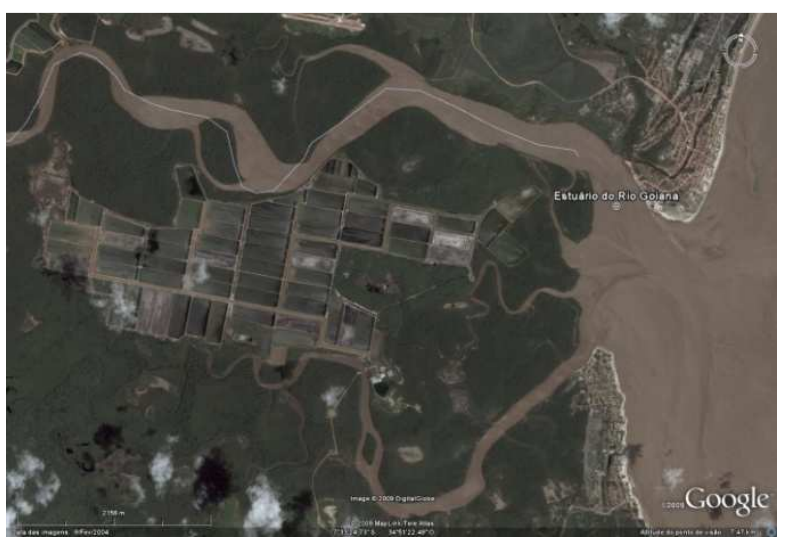

1. Estuary of the Goiana and Megaó Rivers

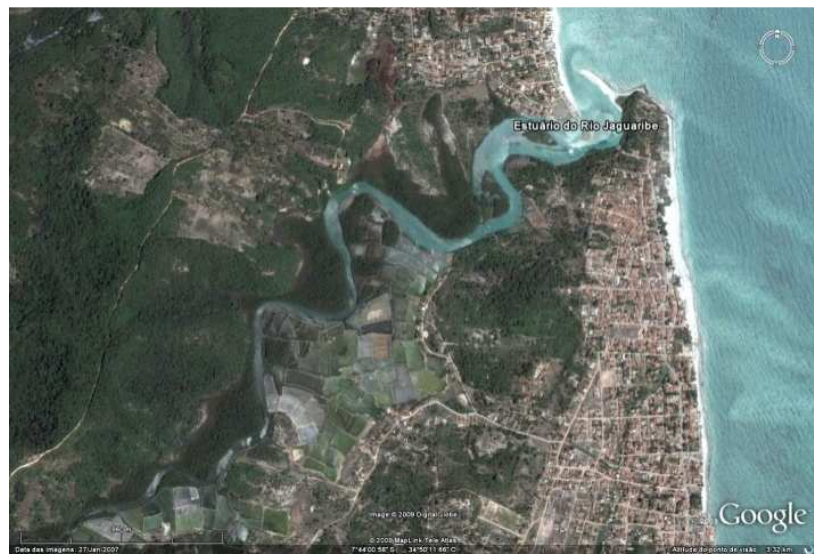

3. Estuary of the Jaguaribe River

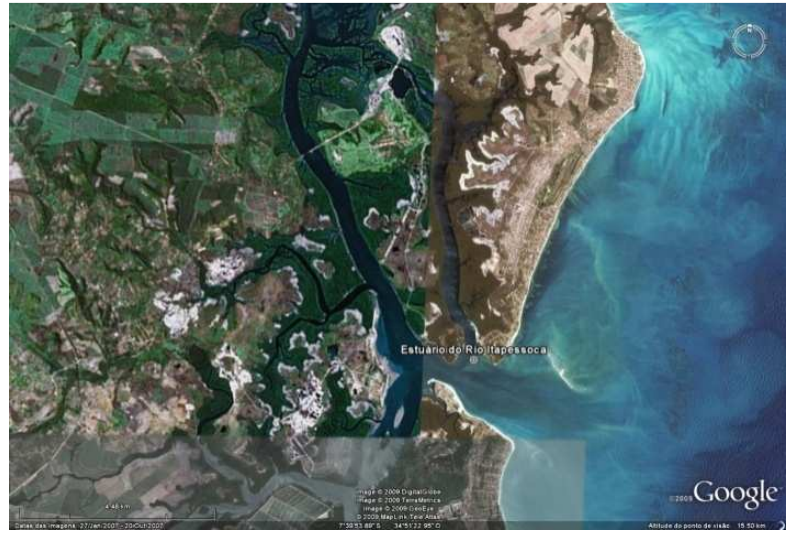

2. Estuary of the Itapessoca River

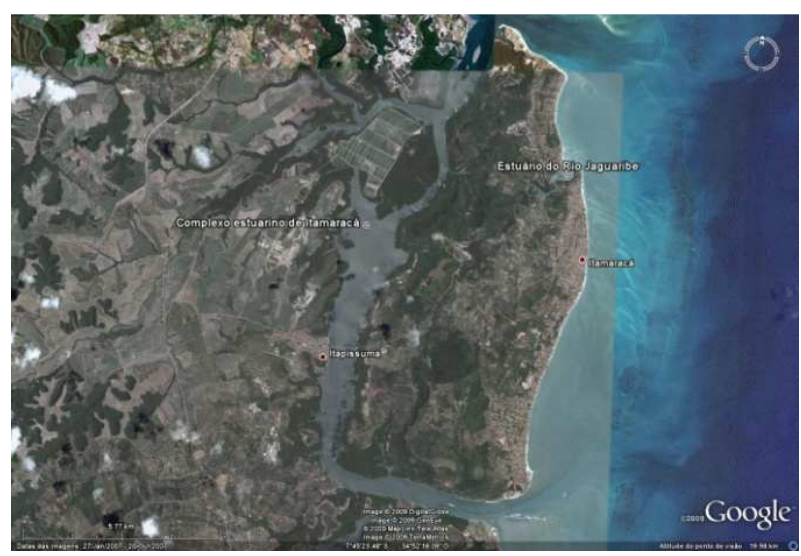

4. Itamaracá Estuary Complex 
PAIVA, C. G. de; ARAUJO, M. E. de . Environmental characterization and spatial distribution of fish fauna in estuaries in the State of Pernambuco, Brazil.

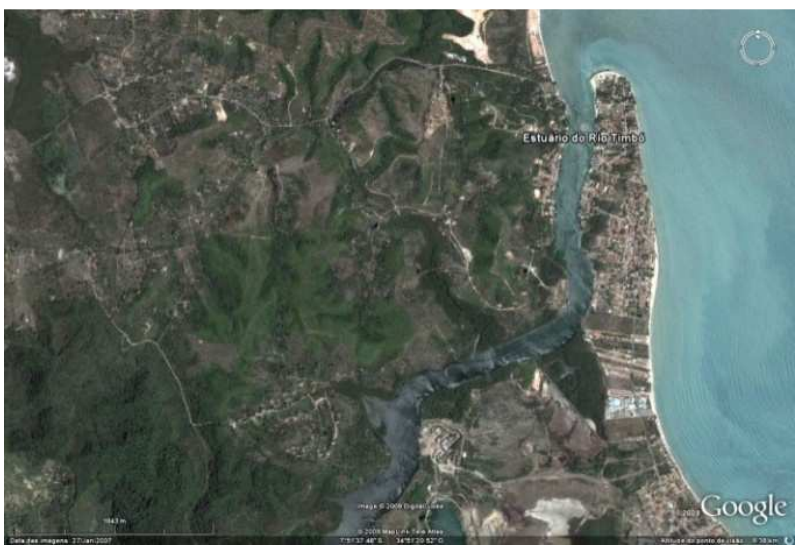

5. Estuary of the Timbó River

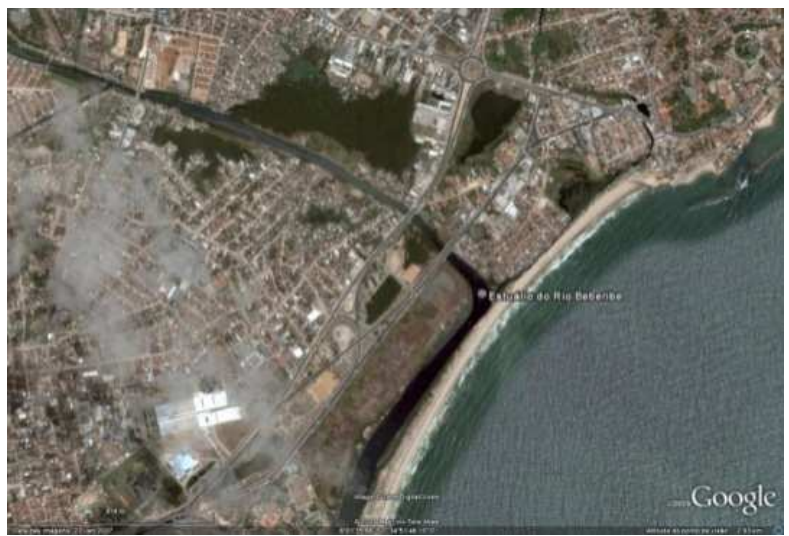

7. Estuary of the Beberibe River

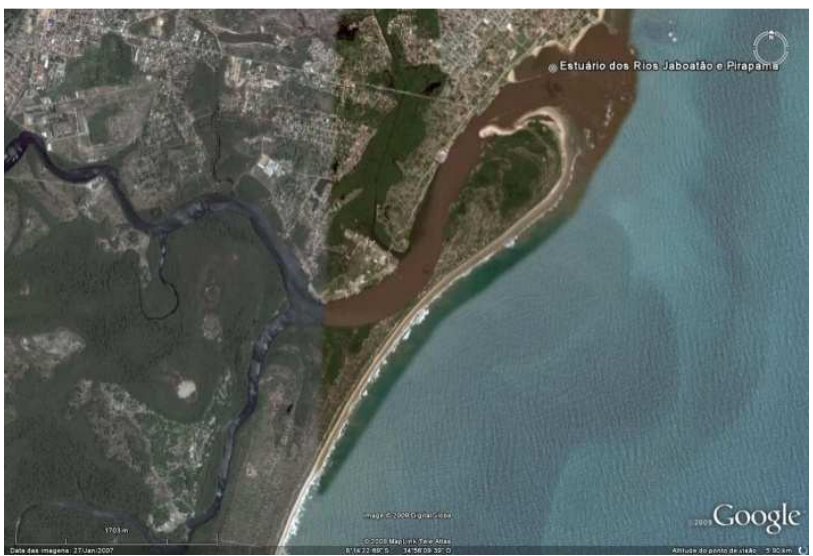

9. Estuaries of the Jaboatão and Pirapama Rivers

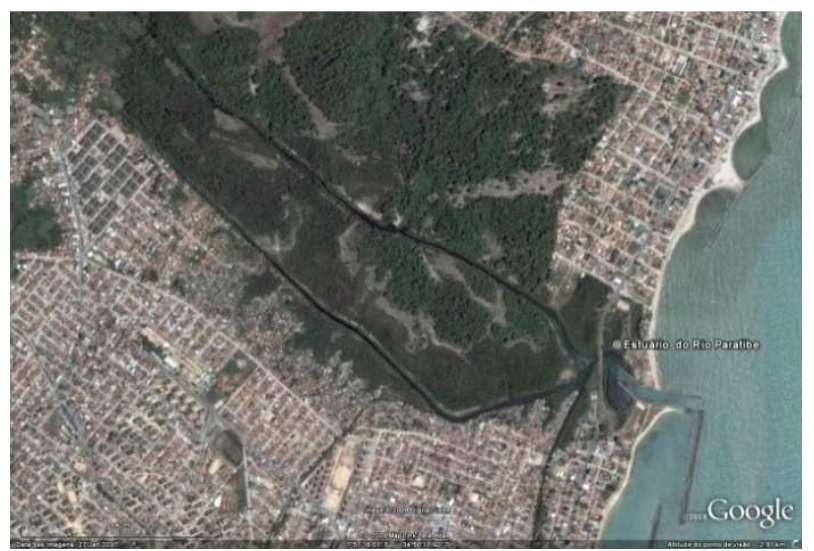

6. Estuary of the Paratibe River

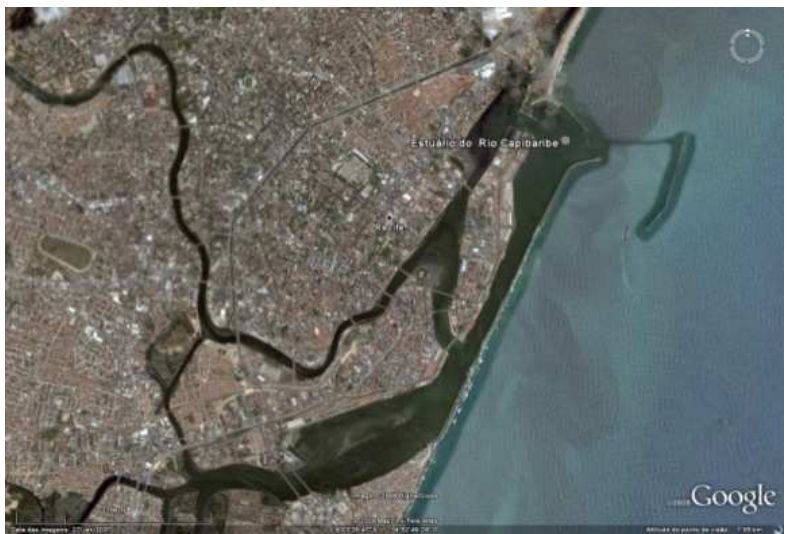

8. Estuary of the Capibaribe River

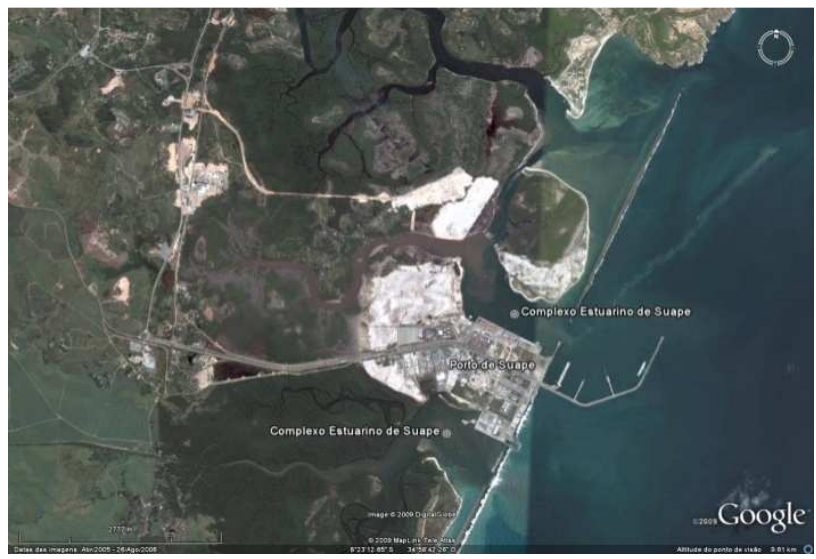

10. Suape Estuary Complex 
Tropical Oceanography, Recife, v. 38, n. 1, p. 1-46, 2010.
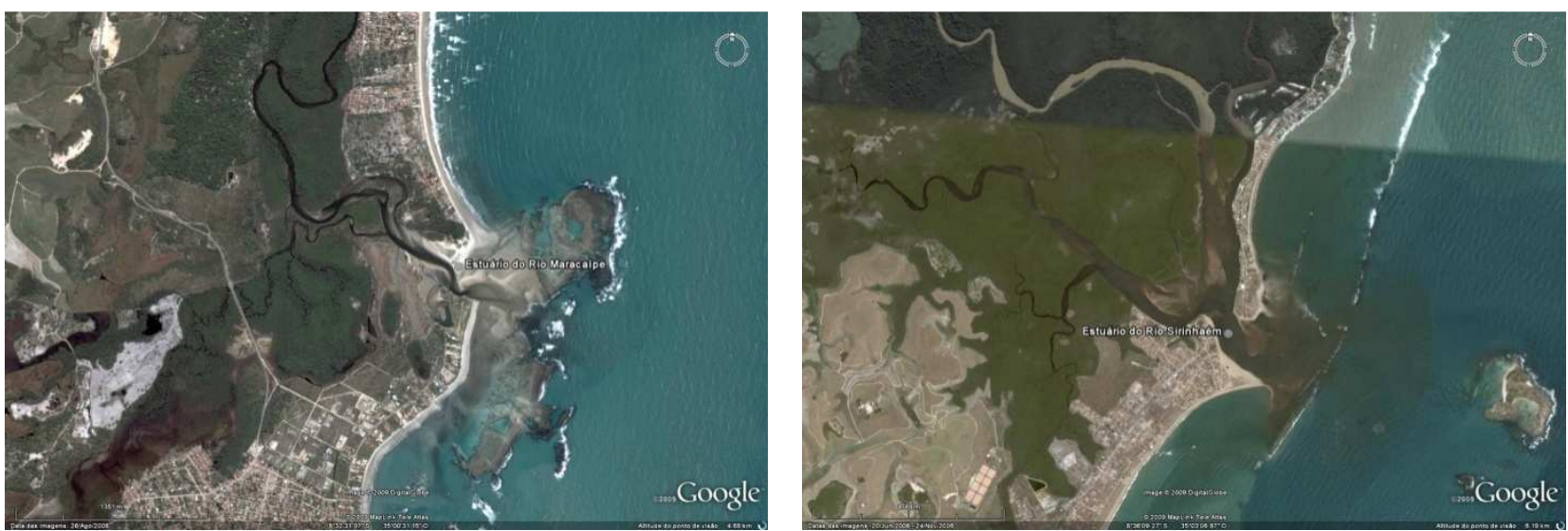

11. Estuary of the Maracaípe River

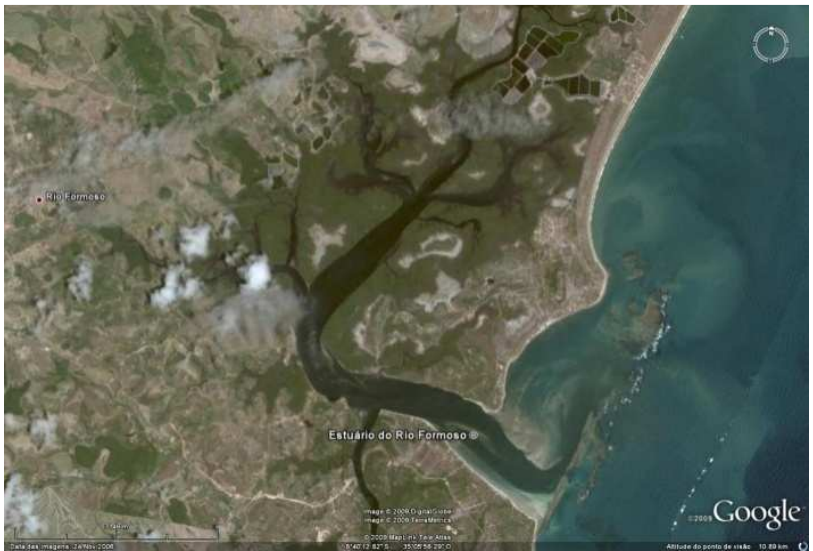

13. Estuary of the Formoso River

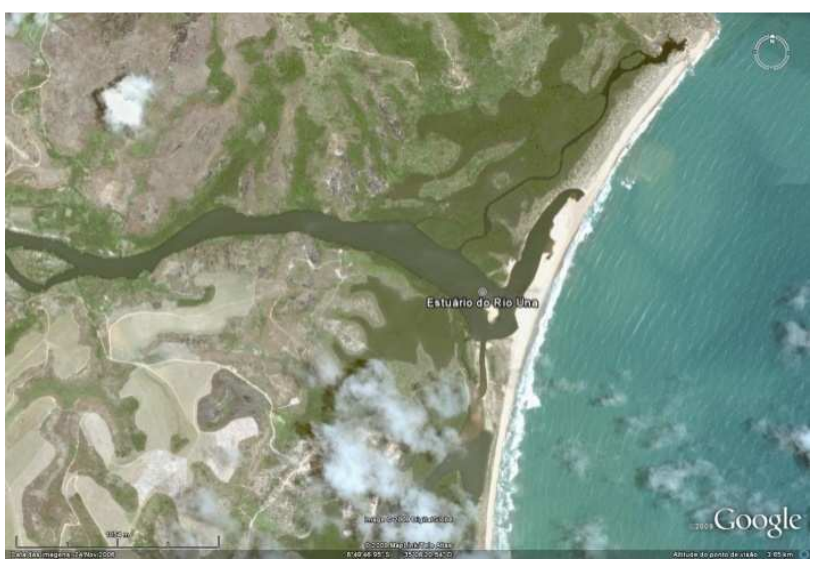

15. Estuary of the Una River
12. Estuary of the Sirinhaém River

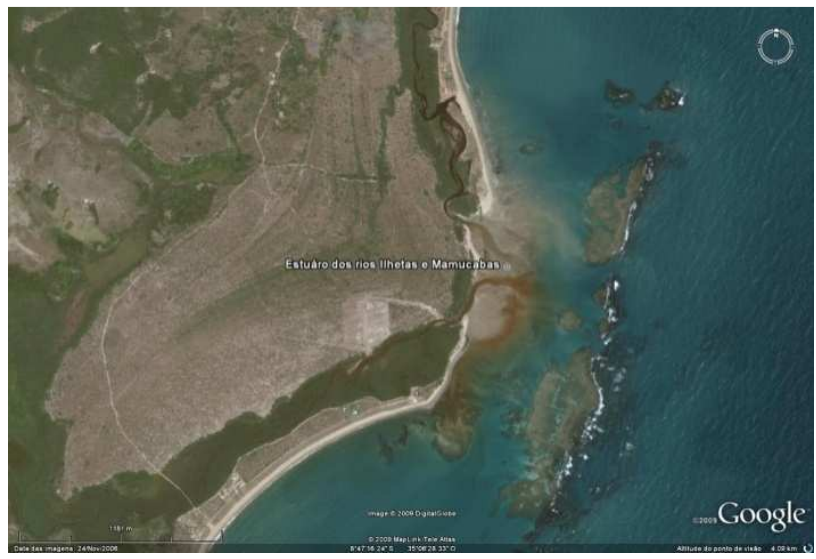

14. Estuaries of the Ilhetas and Mamucabas Rivers

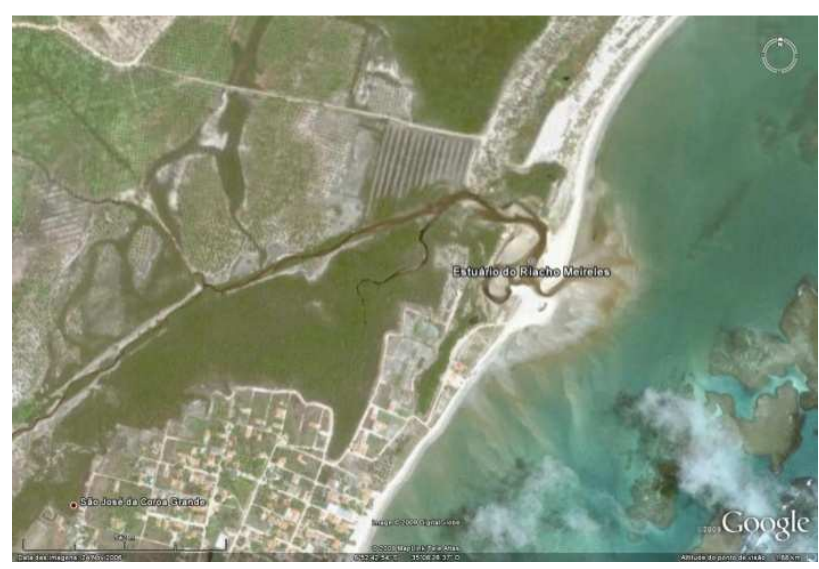

16. Estuary of the Meireles Stream 
PAIVA, C. G. de; ARAUJO, M. E. de . Environmental characterization and spatial distribution of fish fauna in estuaries in the State of Pernambuco, Brazil.

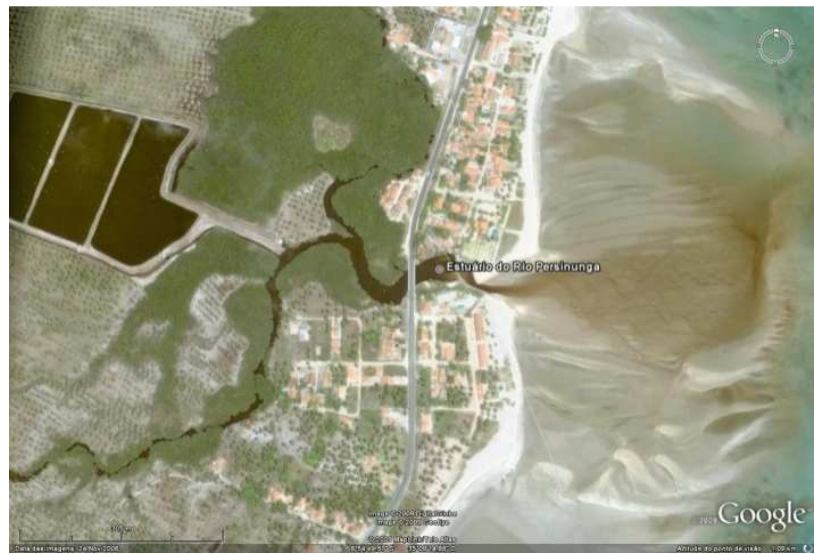

17. Estuary of the Persinunga River

The present study reveals that the estuarine fish fauna in the state of Pernambuco is understudied. There is a greater concentration of studies on the Itamaracá estuary complex and the estuary of the Formoso River, whereas there is no information on some areas, such as the estuaries of the Paratibe, Maracaípe, Sirinhaém and Persinunga Rivers or Meireles Stream. For other estuarine areas, what little information exists dates back to the end of the 1970s (Table I). However, renewed interest began in 2006, with studies by Fittpaldi (2006), Cardoso (2006), Lima (2007), Paiva (2007), Dantas (2008) and Paiva et al. (2008; 2009), who are researchers from the Oceanography Department of the Universidade Federal de Pernambuco. Among the estuaries for which there is information on the fish community, only the estuary of the Formoso River has quantitative data. Moreover, effort, sampling area and type of fishing gear used by the authors of the studies compiled are not standardized, which limits some of the analyses of the present study.

Surveys of the estuarine fish fauna in Pernambuco list 210 valid species, including synonymous species. Data on the presence and absence of these species by estuary are displayed in Appendix 2. Among the 69 families recorded, Carangidae $(n=12)$, Haemulidae $(n=10)$, Gerreidae $(n=9)$ and Ariidae $(n=9)$ were the most specious. The number of species associated to reef environments was 109, corresponding to $51.9 \%$ of the estuarine fish fauna of Pernambuco (Appendix 2). The frequency of occurrence of the species is displayed in Figure 2. Fourteen species were classified as either frequent or very frequent (Figure 3). 


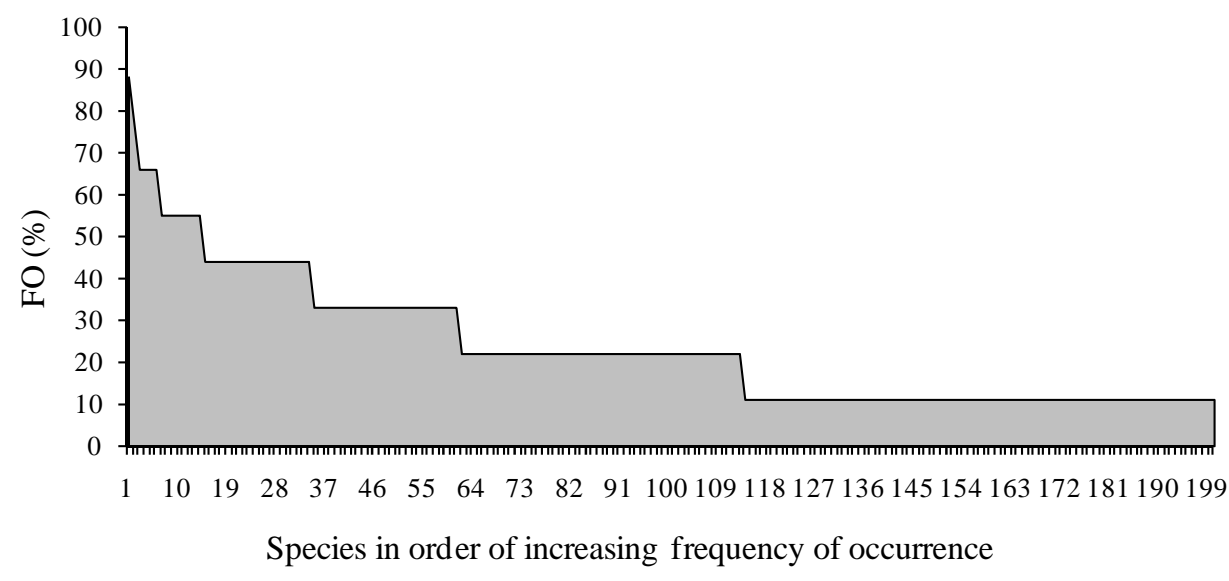

Figure 2 - Distribution of frequency of occurrence of estuarine fish species in Pernambuco.

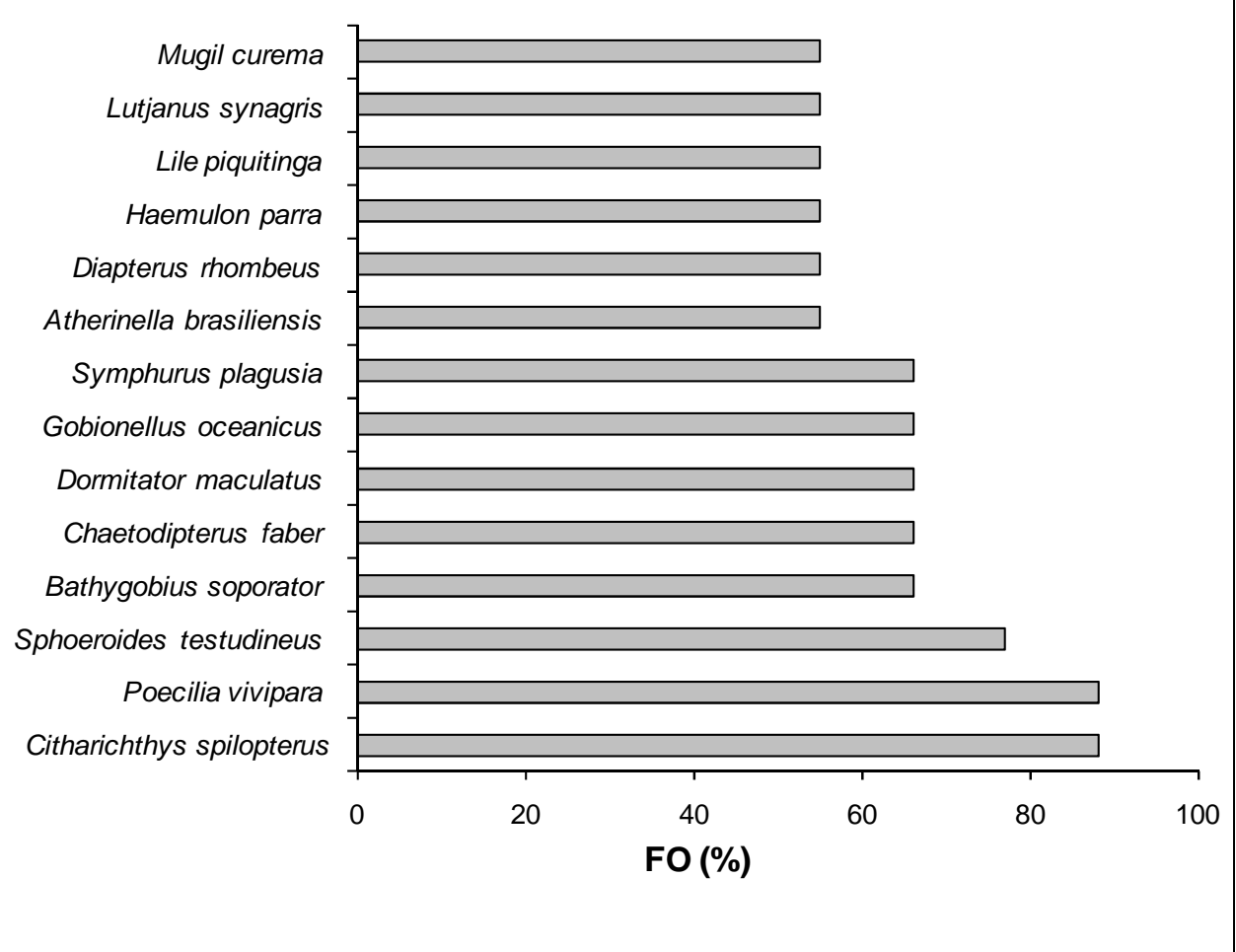

Figure 3 - Species classified as frequent or very frequent in the estuaries of Pernambuco. 
PAIVA, C. G. de; ARAUJO, M. E. de . Environmental characterization and spatial distribution of fish fauna in estuaries in the State of Pernambuco, Brazil.

\section{DISCUSSION}

The estuarine areas of Pernambuco determined in 1970 and 1971 encompassed $250 \mathrm{~km}^{2}$ covered by water and $174 \mathrm{~km}^{2}$ covered by mangroves (Pereira, 1993). A number of these areas are currently destroyed due to deforestation, landfills and pollution from the sugar industry and sewage (Souza \& Sampaio, 2001) as well as shrimp farming enterprises (CPRH, 2009). The study by FIDEM (1987) describes 12 estuarine areas for Pernambuco. In the present study, however, 17 estuarine areas were identified, including the Suape estuary complex and the estuaries of the Meireles Stream and Persinunga River. Moreover, the estuaries of the Maracaípe and Sirinhaém Rivers are considered separately here, as these rivers empty in different locations. The estuary of the Jaguaribe River was separated from the Santa Cruz Channel because it empties into the ocean. The Botafogo River, which is an effluent of this channel, receives a considerable amount of pollutants from residential sewage as well as agricultural and industrial activities (CPRH, 2009).

All interventions in the environment generate positive or negative impacts, causing qualitative and quantitative changes in the flora and fauna components as well as geomorphological, sedimentological and hydrological characteristics (Koening et al., 2002). Between 1973 and 1976, the Pernambuco State Government drafted a directive plan for the implantation a port industrial complex with industrial and commercial purposes in the Suape estuary complex. This plan emerged as a solution for economic growth in the state (Koening et al., 2002). The estuary complex is made up of the Massangana, Tatuoca, Ipojuca and Merepe Rivers (Koening et al., 2002), in that order from north to south. In the Ipojuca River, the partial breaking of the reefs in order to allow its connection to the ocean led to changes in the tide cycle, with a rise in salinity and sedimentation rate (Neumann-Leitão, 1994; Neumann-Leitão et al., 1998). The dredging and construction of channels leads to a large amount of suspended sediment and contaminants. These physical changes result in the destruction of habitats and hydrological alterations, especially the circulation of water, reduction in the concentration of dissolved oxygen (Bohlen et al., 1979). These factors have an impact on the marine communities, such as a reduction in biodiversity, changes in the biological cycle of countless estuarine and marine species, a reduction in fishery production, etc. In a 14-year period, 598ha of mangroves were destroyed in the Suape estuary complex, corresponding to $21.2 \%$ of the area covered by mangroves (Braga et al., 1989). Currently, Suape Port is continuing its expansion, which will certainly have harmful effects on communities in this ecosystem, including the community of fishermen, who use fishery resources in this environment as a source of food and income.

The Meireles Stream and Persinunga River were also not characterized by FIDEM (1987). The first is completely located in the 
municipality of São José da Coroa Grande, with its spring found in the westernmost portion and emptying in the northern portion of this town. In the stretch near the mouth, the channel of this stream was modified to supply a coconut grove, with a likely reduction in the area originally occupied by mangroves (CPRH, 2009).

The estuary of the Persinunga River is located on the border of the states of Pernambuco and Alagoas. The impact of human activities on this estuary is seen from the images used in the present study, especially crop nurseries on its banks, vegetal monoculture and urban expansion near the mouth of the river.

According to FIDEM (1987), the Maracaípe and Sirinhaém Rivers empty into the same estuarine area. However, the present study found that the mouths of these rivers are located in different places. The spring of the Maracaípe River is in the city of Ipojuca, near roadway PE-60, and the river empties near the Pontal de Maracaípe. Its estuarine area is lined with mangroves and sand bars $(\mathrm{CPRH}, 2009)$. Based on the images of this estuary, the mangrove vegetation is quite dense in the innermost areas of its margins and there is a broad sandbank near its mouth, possibly mass sedimentation resulting from deforestation on the banks of this river. The spring of the Sirinhaém River is in the municipality of Camocim de São Félix and its mouth is in the municipality of Sirinhaém. The estuary of this river is broad and complex, with lagoons, numerous islands and extensive mangroves with varied fauna (CPRH, 2009). The main human activity in the estuary of the Sirinhaém River is urban expansion near its mouth.

The Jaguaribe River has a distinct characteristic from the estuaries of the Itamaracá estuary complex. It empties into the ocean, whereas the estuaries of the Botafogo, Igarassu and Paripe Rivers empty directly into the Santa Cruz Channel. The Jaguaribe River is completely contained within Itamaracá Island; its spring is in the central-southern portion and it empties at Sossego Beach. Its estuarine area is occupied by mangroves and former salt works that have been transformed in to artisanal nurseries for fish and shrimp farming ( $\mathrm{CPRH}, 2009)$. The absence of polluting activities in the Jaguaribe River basin has allowed the river and its estuary to remain relatively preserved $(\mathrm{CPRH}, 2009)$. However, nearly the entire left margin of this estuary is occupied by nurseries.

The present survey reveals that there are fewer studies on the fish fauna in the estuaries of Pernambuco in comparison to other regions of the country. There are yet fewer studies that employ quantitative methods, which renders the comparison of this scant material for the determination of the diversity of these fish impossible. Although based on some studies of restricted use (e.g. monographs, dissertations, theses, regional articles and books), the present compilation is the first for the state of Pernambuco and should be broadened considerably as further results are published in scientific journals. 
PAIVA, C. G. de; ARAUJO, M. E. de . Environmental characterization and spatial distribution of fish fauna in estuaries in the State of Pernambuco, Brazil.

The survey lists 210 species belonging to 69 families of estuarine fish fauna in Pernambuco. Among these families, Carangidae, Haemulidae, Gerreidae and Ariidae are the most specious. Compared to other estuaries in Brazil, such as those of the Paciência River (MA) (Castro, 2001), Sepetiba Bay (RJ) (Araújo et al., 1998), Itajaí Açu River (SC) (Hostim-Silva et al., 2002) and Sucuriú River (PR) (Spach et al., 2003), these families are the most diverse in Brazilian estuaries.

Taxonomically, the family Carangidae is quite diversified, encompassing roughly 140 species (Nelson, 2006), the majority of which prefer tropical surface waters near the coast and feed on benthic invertebrates and fish (Paiva et al., (2008). With a coastline of only $187 \mathrm{Km}$, which receives a volume of water from the land in 17 estuaries, the estuaries of Pernambuco are favorable to fish with these characteristics, such as Carangidea and Gerreidae. Species from the family Gerreidae are also among the most abundant in other marine and estuarine ecosystems in northeastern and southeastern Brazil (Santos et al. 1997). In Pernambuco, the most recorded species from this family are Diapterus rhombeus (Cuvier 1829), Eucinostomus argenteus (Baird \& Girard, 1855), Eucinostomus lefroyi (Goode, 1874), Eucinostomus melanopterus (Bleeker, 1863) and Eugerres brasilianus (Cuvier, 1830). These species have demersal habits, feeding mainly on benthic invertebrates (Paiva et al., 2008).

Ariidae is another family in tropical and subtropical coastal marine, estuarine and freshwater environments, generally abundant in shallow coastal waters with a muddy bottom (Araújo, 1988; Andreata et al., 1989). These fish seek the mouths of rivers and estuarine regions during spawning season (Figueiredo \& Menezes, 1978). The most common types of substrate in the estuaries of Pernambuco are sandy-muddy and muddy-sandy (Lira et al., 1979), enabling the growth of the meiofauna and macrofauna and containing organisms such as copepods, nematodes, polychaetes and crustaceans, which serve as food for these catfish (Santos, 2004).

Fish from the family Haemulidae, which is quite species-rich in Pernambuco, occur predominantly in tropical and subtropical seas. Representatives of the genera Pomadasys, Genyatremus, Boridia, Conodon and Orthopristis are more characteristic of sandy beaches and estuarine areas, generally feeding on invertebrates (Menezes \& Figueiredo, 1980; Almeida et al. 2005). Many of the species of Haemulidae compiled here are associated to reef areas, such as Haemulon parra (Desmarest, 1823), H. aurolineatum Cuvier, 1830, H. plumierii (Lacepède, 1801) and Pomadasys corvinaeformis (Steindachner, 1868).

According to Carvalho-Filho et al. (2005), 522 species of marine fish are associated to reefs. These environments are found throughout the entire coast of Brazil, making up part of the Tropical Atlantic System (Ferreira et al., 2004). However, their formation and types vary with the 
latitudinal gradient (Floeter et al., 2001). The occurrence of arenite (or rocky) reefs is recorded from the state of Ceará to Rio Grande do Sul (Guerra \& Manso, 2004). Reefs formed by arenite or coral are common in Pernambuco (Guerra \& Manso, 2004; Ferreira \& Maida, 2006) and are present in $65 \%$ of the deltas of the 17 estuaries in the state.

The diversity, abundance and biomass of fish increase with the complexity of the habitats (Lowe-McConnell, 1999), which is the case with reef environments. Comparing the number of estuarine species estimated for Pernambuco (200) with the total number of marine fish mentioned by Carvalho-Filho et al. (2005), approximately $20 \%$ of reefassociated fish occur in estuarine systems in Pernambuco. According to Haimovici \& Klippel (1999), $20 \%$ of fish of a marine origin use estuarine systems in a permanent manner. The higher percentage of these species in Pernambuco $(52.5 \%)$ is likely due to the aforementioned characteristics of the coast. These results demonstrate the important role estuaries play in the development, protection and reproduction of fish from other ecosystems, such as reefs.

Recent studies on coastal ecosystems in the Caribbean reveal the importance of sea grass and mangroves to populations of reef fish (Mumby et al., 2004). A number of fish species (herbivores, insectivores and piscivores) use mangroves and sea grass fields when juveniles and reefs when adults (Mumby, 2006). Reefs commonly exercise a considerable influence over the composition of estuarine fish fauna (Mumby, 2006; Dorenbosch et al., 2004). This can be seen in the occurrence of typical reef species, such as Abudefduf saxatilis (Linnaeus, 1758), Acanthurus bahianus Castelnau, 1855, Stegastes fuscus (Cuvier, 1830), S. variabilis (Castelnau, 1855) and Canthigaster figuereidoi (Moura \& Castro, 2002), in the estuarine environments of Pernambuco. The majority of estuaries in the state Pernambuco have reefs near their mouths, as exemplified by the estuary complexes of the Santa Cruz Channel and Suape and the estuary of the Formoso River, where the occurrence of these species has been recorded.

Besides the striking presence of reef-associated species in the estuaries, others have broad distribution in the state of Pernambuco, such as Citharichthys spilopterus Günther, 1862 and Poecilia vivipara Bloch \& Schneider, 1801, which are classified here as very frequent. Citharichthys spilopterus occurs mainly in estuaries and hypersaline lagoons, where they live on muddy substrates along the coastline when juveniles to depths of 75 meters when adults (Cervigón et al. 1993). P. vivipara is a freshwater migrant, inhabiting slightly brackish waters in channels and drainage trenches on the margins of wetlands (Keith \& Planquette, 2000). This species is not only abundant in Pernambuco, but also in estuaries down to southeastern Brazil (Fischer et al., 2004), living in water in which the salinity ranges from 0 to 28 (reaching as high as 30 under laboratory conditions) (Amaral et al., 2001). 
PAIVA, C. G. de; ARAUJO, M. E. de . Environmental characterization and spatial distribution of fish fauna in estuaries in the State of Pernambuco, Brazil.

The salinity pattern in the estuaries of Pernambuco generally ranges from oligohaline to euhaline (Coelho et al., 2004). In the estuaries of Suape and the Goiana and Formoso River, for example, the salinity oscillates from 0.05 to 36.5 , which is sufficient to allow both $C$. spilopterus and $P$. vivipara to inhabit these areas. However, this is as yet no record of the former in the estuaries of the Jaguaribe, Capibaribe and Una Rivers or the latter in the estuaries of the Jaguaribe and Capibaribe Rivers and Suape estuary complex.

These facts demonstrate the insufficiency of data for the state of Pernambuco. A few estuaries, such as the Itamaracá estuary complex and the estuary of the Formoso River, have been studied intensively, whereas there are no available data on the fish fauna in other estuaries. These areas are currently undergoing a degradation process due mainly to landfills, residential and industrial sewage, urban development, shrimp farms and the construction/amplification of ports for the sake of economic growth. It is necessary for fostering agencies to encourage further studies in these areas, which are fundamental to the development and reproduction of fish species and, consequently, to an increase in artisanal fisheries.

\section{FINAL CONSIDERATIONS}

The present study reveals that studies are needed on the estuarine fish fauna in the majority of estuaries of Pernambuco. It is likely that a number of species were not catalogued here due to the lack of knowledge on the fish fauna.

The present study also allowed quantifying an important portion of fish from other ecosystems, such as reefs, that use estuaries for development, feeding and reproduction. The degradation of these ecosystems can considerably compromise the diversity of fish species within the estuaries as well as in ecosystems linked to estuaries. Thus, the results of the present study may serve as a basis for environmental management and monitoring projects. Environmental agencies should act more effectively by increasing the number of supervisors in order to impede the use of nets with small mesh sizes, which capture a high number of juveniles. Many of these juveniles are discarded due to their lack of commercial value, such as globefish and Gobiidae, and even those with commercial importance are eliminated for having an inadequate size for the market. Environmental education and management plans should be implanted for conservation not only of the fish fauna that use the estuaries, but also the entire biota of the estuaries of Pernambuco and Brazil.

\section{ACKNOWLEDGMENTS}

To Prof. Dr. João Paes Viera and Beatrice P. Ferreira for his valuable suggestions regarding the reformulation of this paper; to the 
fostering agencies Fundação de Amparo à Ciência e Tecnologia do Estado de Pernambuco (FACEPE), Coordenação de Aperfeiçoamento de Pessoal de Nível Superior (CAPES) and Conselho Nacional de Pesquisa (CNPq) for the study grants awarded to the authors.

\section{REFERENCES}

ALMEIDA, Z.S.; V. FONSECA-GENEVOIS \& VASCONCELOS-FILHO, A.L. Alimentação de Achirus lineatus (Teleostei, Pleuronectiforme: Achiridae) em Itapissuma - PE. Boletim do Laboratório de Hidrobiologia, v.10, p.79-95, 1997.

ALMEIDA, Z.S.; ACIOLI, F.D. \& VASCONCELOS-FILHO, A.L. Levantamento da ictiofauna na área de Itapissuma (Itamaracá - PE). Pesq. Foco, São Luís, v.6, n.7, p.79-107, 1998.

ALMEIDA, Z.S.; SILVA-NUNES, J.L. \& ALVES, M.G. Dieta alimentar de Genyatremus luteus (Bloch, 1790) - (Teleostei, Perciformes, Haemulidae) na Baía de São José, Maranhão, Brasil. Atlântica, Rio Grande, v. 27, n.1, p. 39-47, 2005.

AMARAL, M.C.; BONECKER, A.C.T. \& ORTIZ, C.H.D. Activity Determination of $\mathrm{Na}+\mathrm{K}+-$ ATPase and $\mathrm{Mg}++-$ ATPase Enzymes in the Gill of Poecilia vivipara (Osteichthyes, Cyprinodontiformes) in Different Salinities. Brazilian Archives of Biology and Technology, v. 44, n. 1, p. 1-6, 2001.

ANDREATA, J.V.; SAAD, A.M. \& BARBIERI, L.R.R. Associação e distribuição das espécies de peixes na Laguna de Marapendi, Rio de Janeiro, no período de março de 1985 a fevereiro de 1987. Memorial do Instituto Oswaldo Cruz, v.84, Supl. IV, p.45-51, 1989.

ARAÚJO, F.G. Distribuição, abundância relativa e movimentos sazonais de bagres marinhos (Siluriformes, Ariidae) no estuário da lagoa dos Patos (RS), Brasil. Revista Brasileira de Zoologia, v.5, n.4, p. 509-543, 1988.

ARAÚJO, M.E., TEIXEIRA, J.M.C. \& A.M.E. OLIVEIRA. Peixes estuarinos marinhos do nordeste brasileiro. Guia Ilustrado. Editora Universitária, UFPE e EFC, Recife, 2004, 260p.

ARAÚJO, F.G.; A.G. CRUZ-FILHO; M.C.C. AZEVÊDO \& A.C.A. SANTOS. Estrutura da comunidade de peixes demersais da Baía de Sepetiba, RJ.

Revista Brasileira de Biologia, v. 58, n. 3, p. 417-430, 1998.

AZEVEDO, S.B. \& GUEDES, D.S. Estudo ecológico da região de Itamaracá, Pernambuco Brasil. X. Novas ocorrências de peixes.

Trabalhos Oceanográficos da Universidade Federal de Pernambuco, Recife, v.15, p. 331-342, 1980.

BLABER, S.J.M. Tropical estuarine fishes: ecology, exploitation and conservation. Queensland, Australia Blackwell Science, 2000, 372p. 
PAIVA, C. G. de; ARAUJO, M. E. de . Environmental characterization and spatial distribution of fish fauna in estuaries in the State of Pernambuco, Brazil.

BOHLEN, W.F.; CUNHDY, D.F.\& TRAMONTANO, J.M. Suspended material distribution in the wake of estuarine channel dredging operations.

Estuarine and Coastal Marine Science, v.9, n.6, p. 699-711, 1979.

BRAGA, R.A.P.; MOURA, H. \& DUARTE, M.T. Impactos ambientais sobre a estrutura do manguezal de Suape. p. 32-42. In:

UNIVERSIDADE FEDERAL DE PERNAMBUCO. Departamento de Biologia Geral. Laboratório de Ecologia. Projeto Avaliação de Impactos Ambientais em Zonas Estuarinas de Pernambuco. Recife, 1989.

CABERTY, S.; BOUCHEREAU, J. \& CHAVES, P.T. Organisation et fonctionnement trophiques de l'assemblage ichtyque d'um écosystème lagunaire à mangrove antillais au moyen de l'indice trophique de contribution. Cahier de Biologie Marine, v.45, p.243-254, 2004.

CAMARGO, M. \& ISAAC, V.J. Ictiofauna estuarina. p.105-142. In: M.E.B. Fernandes (Org.). Os manguezais da costa Norte do Brasil. São Luís: Fundação Rio Bacanga, 2003.

CARDOSO, H.G.V. Morfologia trófica e hábito alimentar de Bathygobius soporator e Lutjanus synagris (Actinopterygii) no estuário do rio Formoso - PE, 2006. Monografia de Especialização. Programa de Pós-Graduação em Oceanografia, Universidade Federal de Pernambuco, 2006.

CARVALHO-FILHO et al. Peixes recifais do Brasil: uma síntese. In: XVI Encontro Brasileiro de Ictiologia, João Pessoa, 2005.

CASTRO, M.F. Abundancia, distribuição e desenvolvimento das fases iniciais de peixes no estuário do Rio Formoso, Pernambuco Brasil. Dissertação de Mestrado. Programa de Pós-Graduação em Recursos Pesqueiros e Aqüicultura, 2005, $72 \mathrm{f}$.

CASTRO, A.C.L. Diversidade da assembléia de peixes em igarapés do estuário do rio Paciência (MA - BRASIL), Atlântica, v. 23, p. 61-72, 2001.

CAVALCANTI, E.F.; VASCONCELOS-FILHO, A.L.; SOUZA, S.T. \& GUEDES, D.S. Novas ocorrências de peixes para o Canal de Santa Cruz, Itamaracá,PE. Caderno Ômega UFRPE (Série Ciências Aquáticas), Recife, v.4, p. 7-16, 1998.

CERVIGÓN, F. et al. Fichas FAO de identificación de especies para los fines de la pesca. Guía de campo de las especies comerciales marinas y de aquas salobres de la costa septentrional de Sur América. FAO, Rome. 513 p. Preparado con el financiamento de la Comisión de Comunidades Europeas y de NORAD, 1993.

COELHO, P.A.; L.M.A. BATISTA-LEITE; M.A.C. SANTOS \& TORRES, M.F.A. O Manguezal. In: ESKINAZI-LEÇA, E.; S. NEUMANN-LEITÃO; M.F. COSTA. (Orgs.). Oceanografia um cenário tropical. Universidade Federal de Pernambuco, Centro de Tecnologia e Geociências, Departamento de Oceanografia, p.641-688, 2004. 
$\mathrm{CPRH}$, Diagnóstico sócioambiental - Litoral sul de Pernambuco. Hidrografia, 2009a. Disponível em: <http://www.cprh.pe.gov.br/downloads/13_Hidrografia.pdf.>. Acesso: abr. 2009.

CPRH, Diagnóstico sócioambiental - Litoral norte de Pernambuco. Recursos hídricos superficiais. 2009b. Disponível em: <http://www.cprh.pe.gov.br/downloads/24_Recursos_Hidricos_Superficia is.pdf> Acesso em: abr. 2009.

DANTAS, D.V. Variação espaço-temporal das espécies da família Ariidae (Siluriformes) no estuário do rio Goiana (PE/PB - Brasil). Dissertação de Mestrado. Departamento de Oceanografia. Universidade Federal de Pernambuco, 2008, 63f.

DORENBOSCH, M.; M.C. VAN RIEL; I. NAGELKERKEN \& VAN DER VELGE, $G$. The relationship of reef fish densities to the proximity of mangrove and seagrass nurseries. Estuarine and Coast Shelf Science, v. 60, n. 37-48, 2004.

\section{EL-DEIR, A.C.A. Composição e distribuição espaço-temporal de} formas iniciais de peixes no estuário do rio Jaguaribe, Itamaracá, litoral norte de Pernambuco, Brasil. Tese (Doutorado em Zoologia), Universidade Federal da Paraíba, Centro de Ciências Exatas e da Natureza, Departamento de Sistemática e Ecologia, Programa de PósGraduação em Ciências Biológicas. 2005.

ESCHMEYER, W.N. Catalog of Fishes electronic version (updated 20/05/2008), 2008. Disponível em:

<http://www.calacademy.org/research/ichthyology/catalog/fishcatsearch .html>. Acesso em mai. 2008.

ESKINAZI, A.M. Lista preliminar dos peixes estuarinos de Pernambuco e estados vizinhos (Brasil). Trabalhos Oceanográficos da Universidade Federal de Pernambuco, Recife, v.9/11, p. 265-274, 1967/1969.

ESKINAZI, A.M. Peixes do Canal de Santa Cruz, Pernambuco, Brasil.

Trabalhos Oceanográficos da Universidade Federal de Pernambuco, Recife, v.13, p. 283-302, 1972.

FALCÃO, E.C.S. Estrutura da comunidade de formas iniciais de peixes em uma gamboa do estuário do rio Catuama, Pernambuco, Brasil. Dissertação (Mestrado em Oceanografia). Universidade Federal de Pernambuco, Centro de Tecnologia e Geociências, Departamento de Oceanografia. Recife, 2007,78f.

FERRARIS, C.J. Checklist of catfishes, recent and fossil (Osteichthyes: Siluriformes), and catalogue of siluriform primary types. Zootaxa, v.1418, p.1-628, 2007. 
PAIVA, C. G. de; ARAUJO, M. E. de . Environmental characterization and spatial distribution of fish fauna in estuaries in the State of Pernambuco, Brazil.

FERREIRA, B.P.; M. Maida \& Souza, A.E.T. Levantamento inicial das comunidades de peixes recifais na região de Tamandaré, Pernambuco. Boletim Técnico Científico do CEPENE, v.3, n.1, p. 213-230, 1995.

FERREIRA, C.E.L. et al. Trophic structure patterns of Brazilian reef fishes: a latitudinal comparison. Journal of Biogeography, n.31, p. 10931106, 2004.

FERREIRA, B.P. \& MAIDA, M. Monitoramento dos recifes de coral do Brasil: situação atual e perspectivas. Biodiversidade 18. Ministério do Meio Ambiente, Secretaria de Biodiversidade e Florestas, Brasília - DF., 2006.

FIDEM, Proteção das áreas estuarinas. Série de Desenvolvimento Urbano e Meio Ambiente, Fundação de Desenvolvimento da Região Metropolitana do Recife - FIDEM, Recife, 1987.

FIGUEIREDO, J.L. \& N.A. MENEZES. 1978. Manual de peixes marinhos do sudeste do Brasil. II Teleostei. São Paulo, Museu de Zoologia, Universidade de São Paulo, 110p.

FISHER, L.G.; PEREIRA, L.E.D. \& VIEIRA, J.P. Peixes estuarinos e costeiros. Série Biodiversidade do Atlântico Sudoeste. Ecoscientia, Rio Grande, 2004, 126p.

FITTPALDI, C.D. Bioecologia de Citharichthys spilopterus Günther, 1862 (Actinopterygii: Paralichthyidae) no estuário do rio Formoso (PE). Monografia de Especialização. Programa de Pós-Graduação em Oceanografia, Universidade Federal de Pernambuco, 2006.

FLOETER, S.R., GUIMARÃES, R.Z.P., ROCHA, L.A., FERREIRA, C.E.L., RANGEL, C.A. \& GASPARINI, J.L. Geographic variation in reef-fish assemblages along the Brazilian coast. Global Ecology and Biogeography, v.10, p. 423-433, 2001.

FROESE, R. \& PAULY, D. FishBase, 2008. Disponível em: <http://www.fishbase.org.> Acesso: out. 2008.

GUERRA, N.C. \& MANSO, V.A.V. Beachrocks (recifes de arenito), p. 109130. In: Eskinazi-Leça, E.; S. Neumann-Leitão \& M.F. Costa (Org.).

Oceanografia, um cenário tropical. Bagaço, Recife, 2004, 761p.

HAIMOVICI, M. \& KLIPPEL, S. Diagnóstico da biodiversidade dos peixes teleósteos demersais marinhos e estuarinos do Brasil, 1999. Disponível em: <http://www.bdt.org.br/workshop/costa> Acesso: mai. 2008.

HOSTIM-SILVA, M.; VICENTE, M.J.D.; FIGNA, V. \& J.P. ANDRADE. Ictiofauna do rio Itajaí Açu, Santa Catarina, Brasil. Notas Técnicas FACIMAR, v. 6, p. 127-135, 2002.

HUMANN, P. \& DELOACH, N. Reef Fish Identification: Florida

Caribbean Bahamas. New World Publications, Inc., 2002, 481p. 
KEITH, P. \& PLANQUETTE, P. Atlas des poissons d'eau douce de Guyane (tome 2, fascicule I). Publications scientifiques du Muséum national d'Histoire naturelle, Paris, 2000, 286 p.

KOENING, M.L.; ESKINAZI-LEÇA, E. ; NEUMANN-LEITÃO, S. \& MACÊDO. S.J. Impactos da construção do Porto de Suape sobre a comunidade fitoplanctônica. Acta Botânica Brasílica, v. 16, n.4, p. 407-420, 2002.

LIMA, M.V.F.M. Distribuição espacial e temporal das famílias Gerreidae e Centropomidae (Actinopterygii) em um estuário tropical: um estudo de caso. Monografia de Graduação, Universidade Federal Rural de Pernambuco, Departamento de Biologia, 2007.

LIRA, L.; M.C. ZAPATA, \& V.G. FONSECA. Aspectos da dinâmica do estuário do Rio Formoso, PE. Cadernos Omega da Universidade Federal de Pernambuco, Recife, v. 3, n. 1/2, p. 133-156. 1979.

LIRA, A. et al., A. Manguezais, importância de sua preservação: aspectos da degradação dos manguezais de Pernambuco. Recife: Escola Recanto, 1992. 87 p.

LOWE-MCCONNEL, R.H. Estudos ecológicos de comunidades de peixes tropicais. EDUSP, São Paulo, 1999, 534p.

MACÊDO, S.J.; K. MUNIZ \& M.J. FLORES-MONTES. Hidrologia da região costeira e plataforma continental do estado de Pernambuco, p. 255-286. In: E. ESKINAZI-LEÇA; S. NEUMANN-LEITÃO \& M.F. COSTA (Eds). Oceanografia, um cenário tropical. Recife, Bagaço, 761p, 2004.

MARCENIUK, A.P. \& MENEZES, N.A. Systematics of the family Ariidae (Ostariophysi, Siluriformes), with a redefinition of the genera. Zootaxa, v. 1416, n. 1-126, 2007.

MEDEIROS, T.N. Uso comparativo de atrator luminoso e rede de arrasto na captura de larvas de peixes no estuário do Rio Formoso, Pernambuco, Brasil. Dissertação (Mestrado em Recursos Pesqueiros e Aquicultura).

Universidade Federal Rural de Pernambuco, Programa de Pós-Graduação em Recursos Pesqueiros e Aquicultura, Recife. 2005, $46 \mathrm{f}$.

MENEZES, N.A. \& FIGUEIREDO J.L. Manual de peixes marinhos do sudeste do Brasil. III. Teleostei. São Paulo, Museu de Zoologia, Universidade de São Paulo, 1980, 90p.

MENEZES, N.A.; P.A. BUCKUP; J.L. FIGUEIREDO \& MOURA, R.L.

Catálogo das espécies de peixes marinhos do Brasil. Museu de Zoologia da Universidade de São Paulo, São Paulo, 2003, 160p.

MIRANDA, L.B.; CASTRO, B.M. \& KJERFVE, B. Pricípios de Oceanografia Física de Estuários. São Paulo: Edusp - Editora da Universidade de São Paulo, São Paulo, 2002, 411 p.

MUMBY, P.J. Connectivity of reef fish between mangroves and coral reefs: Algorithms for the design of marine reserves at seascape scales.

Biological Conservation, v.128, p. 215-222, 2006. 
PAIVA, C. G. de; ARAUJO, M. E. de . Environmental characterization and spatial distribution of fish fauna in estuaries in the State of Pernambuco, Brazil.

MUMBY, P.J. et al. Mangroves enhance of coral reef fish communities in the Caribbean. Nature, v.427, p. 533-536, 2004.

NELSON, J.S. Fishes of the world. John Wiley and Sons, Inc. New York. 4. ed., 2006, 601p.

NEUMANN-LEITÃO, S. Impactos antrópicos na comunidade zooplanctônica estuarina. Porto de Suape-PE-Brasil. Tese Doutorado. Universidade de São Paulo, São Carlos, 1994.

NEUMANN, V.H.; MEDEIROS, C.; PARENTE, L.; NEUMANN-LEITÃO, S. \& KOENING, M.L., Hydrodynamism, sedimentology, geomorphology and plankton changes at Suape area (Pernambuco-Brazil) after a Port Complex Implantation. Anais Academia Brasilleira de Ciências, v.70, n.2, p. 313-323, 1998.

OLIVEIRA, A.M.E. Distribuição dos peixes nos estuários do nordeste brasileiro de acordo com a salinidade da água. Dissertação de Mestrado. Universidade Federal do Rio de Janeiro, 1979, $79 f$.

PAIVA, A.C.G.; CHAVES, P.T.C. \& ARAÚJO, M.E. Estrutura e organização trófica da ictiofauna de águas rasas em um estuário tropical. Revista Brasileira de Zoologia, v.25, n.4, p.579-846, 2008.

PAIVA, A.C.G.; LIMA, M.F.V.; SOUZA, J.R.B. \& ARAÚJO, M.E. Spatial distribution of the estuarine ichthyofauna of the Rio Formoso (Pernambuco, Brazil), with emphasis on reef fish. Revista Brasileira de Zoologia, v.26, n.2, p. 266-278, 2009.

PAIVA, P.L. Distribuição espacial e temporal de clupeiformes (Actinopterygii) em um estuário tropical: um estudo de caso. Monografia de Graduação, Universidade Federal Rural de Pernambuco, Departamento de Biologia, 2007.

PEREIRA, S.B. Aspectos ecológicos de áreas de manguezais em Pernambuco. ANAIS da $45^{\circ}$ Reunião Anual da Sociedade Brasileira para o Progresso da Ciência. Universidade Federal de Pernambuco, 1993, p.885.

PRITCHARD, D. Observations of circulation in coastal plain estuaries. In: G. Lauff (Ed.), Estuaries. American Association for the Advancement of Science. Publ. No 83, Washington, D. C., p. 37-44, 1967.

REIS, R.E.; Kullander, S.O. \& Ferraris, S.J. Check List of the Freshwater Fishes of South and Central America. Edipucrs, Porto Alegre, 2003, 729p.

ROZAS, L.P. \& ZIMMERMAN, R.J. Small-scale patterns of nekton use among marsh and adjacent shallow nonvegetated areas of the Galveston Bay Estuary, Texas (USA), Marine Ecology Progress Series, v.193, p. 217-239, 2000.

SANTOS, F.L.B. Levantamento da ictiofauna do estuário do rio Formoso (Pernambuco, Brasil) através da pesca de camboa. 
Dissetaçao de Mestrado. Departamento de Oceanografia, Universidade Federal de Pernambuco, 2001, 76f.

SANTOS, A.C.A.; F.G. ARAúJO; A.G.C. FILHO \& M.C.C. AZEVEDO.

Distribuição e abundância relativa de Gerreidae (Osteichthyes, Perciformes) na Baia de Sepetiba, RJ. Arquivos de Biologia e

Tecnologia., Rio de Janeiro, v. 4, n. 3, p. 672-686, 1997.

SANTOS, A.F. Ecologia alimentar do bagre-amarelo, Arius spixii

(Agassiz, 1829) (Siluriformes: Ariidae) na enseada de

Caraguatatuba, São Paulo. Monografia de Graduação, Curso Ciências

Biológicas, Centro Universitário da Fundação de Ensino Octávio Bastos,

São Paulo, 2004.

SOUZA, M.M.A. \& SAMPAIO, E.V.S.B. Variação temporal da estrutura dos bosques de mangue de Suape - PE após a construção do porto. Acta

Botanica Brasílica, v.15, n.1, p. 1-12, 2001.

SOUZA, R.C. Ictioplâncton do complexo estuarino de Itapessoca, litoral norte de Pernambuco, PE. Tese (Doutorado em Ecologia e Recursos Naturais). Universidade Federal de São Carlos, Centro de Ciências Biológicas e da Saúde, Programa de Pós-Graduação em Ecologia e Recursos Naturais, São Carlos, São Paulo. 2003. 83f.

SPACH, H.L.; C. SANTOS \& R.S. GODEFROID. Padrões temporais na assembléia de peixes na gamboa do Sucuriú, Baía de Paranaguá, Brasil.

Revista Brasileira de Zoologia, v. 20, n. 4, p. 591-600, 2003.

TEIXEIRA, S.F. \& S.S. CAMPOS. Ocorrência de Mycteroperca bonaci (Poey, 1860) (Teleostei: Serranidae: Epinephelinae) no Canal de Santa Cruz, Pernambuco, Brasil. Trabalhos Oceanográficos da Universidade Federal de Pernambuco, Recife, v.28, n.2, p.67-72, 2000.

VASCONCELOS-FILHO, A.L. Interações tróficas entre peixes do Canal de Santa Cruz (Pernambuco - Brasil). Tese de Doutorado. Programa de Pós-Graduação em Oceanografia. Universidade Federal de Pernambuco, 2001, 184f.

VASCONCELOS-FILHO, A.L.; GUEDES, D.S. \& D.G. SOBRINHO.

Taxonomia e ecologia da fauna ictiológica da área de Suape (Pernambuco

- Brasil). Trabalhos Oceanográficos da Universidade Federal de Pernambuco, v.21, p.305-343.

VASCONCELOS-FILHOS, A.L.; ACIOLI, F.D. \& D.S. GUEDES. Peixes do estuário do Rio Paripe. Trabalhos Oceanográficos da Universidade Federal de Pernambuco, v.23, p. 65-77, 1994/1995.

VASCONCELOS-FILHO, A.L.; CAVALCANTI, E.F. \& SOUZA, S.T. Composição e distribuição da fauna ictiológica no Canal de Santa cruz. Revista Nordestina de Zoologia, v.1, n.1, p.247-262, 1994.

VASCONCELOS-FILHO, A.L. \& OLIVEIRA, A.M.E. Ictiofauna. In: Barros, H.M.; E. Eskinazi-leça; S.J. Macêdo; T. Lima (Eds.). Gerenciamento 
PAIVA, C. G. de; ARAUJO, M. E. de . Environmental characterization and spatial distribution of fish fauna in estuaries in the State of Pernambuco, Brazil.

Participativo de Estuários e Manguezais, Ed. Universitária, Recife, 2000, 252p.

VIDY, G. Estuarine and mangrove systems and the nursery concept: which is which? The case of the Sine-Saloum system (Senegal).

Wetlands Ecology and Management, v.8, p.37-51, 2000.

YÁNEZ-ARANCÍBIA, A. Taxonomia, ecologia y estructura de las comunidades de peces em lagunas costeras com bocas efimeras del Pacifico México. Centro Cienc. Del Mar Y Limnol. Univ. Nal. Autón. México, 1978. 
APPENDIX I - Characterization of estuarine areas in Pernambuco.

\begin{tabular}{|c|c|c|c|c|c|c|}
\hline $\begin{array}{l}\text { Physiographic } \\
\text { factors }\end{array}$ & $\begin{array}{l}\text { Goiana and } \\
\text { Megaó Rivers }\end{array}$ & $\begin{array}{l}\text { Itapessoca } \\
\text { River }\end{array}$ & $\begin{array}{l}\text { Jaguaribe } \\
\text { River }\end{array}$ & $\begin{array}{l}\text { Itamaracá } \\
\text { Complex }\end{array}$ & Timbó River & Paratibe River \\
\hline Area (ha) & 4776ha & 3998ha & 212ha & 3602ha & 1397ha & - \\
\hline $\begin{array}{l}\text { Estuary } \\
\text { characteristics }\end{array}$ & $\begin{array}{l}\text { Vast area of } \\
\text { rivers, streams, } \\
\text { lagoons, small } \\
\text { channels of } \\
\text { islands covered } \\
\text { by dense } \\
\text { mangrove } \\
\text { vegetation. }\end{array}$ & $\begin{array}{l}\text { Area of ecological } \\
\text { interest due to its } \\
\text { natural } \\
\text { characteristics. }\end{array}$ & $\begin{array}{l}\text { Most important } \\
\text { waterway } \\
\text { originating on } \\
\text { Itamaracá } \\
\text { Island; } \\
\text { approximately } 9 \\
\text { Km long, } \\
\text { emptying into } \\
\text { the Atlantic } \\
\text { Ocean. }\end{array}$ & $\begin{array}{l}\text { Estuary complex involving } \\
\text { the channel and adjacent } \\
\text { estuaries; high primary } \\
\text { and secondary } \\
\text { productivity, permitting } \\
\text { intensive fishery activity. }\end{array}$ & $\begin{array}{l}\text { Expressive mangrove } \\
\text { vegetation, considered one } \\
\text { of the most fertile } \\
\text { estuaries in the region, } \\
\text { with high degree of } \\
\text { primary productivity. }\end{array}$ & $\begin{array}{l}\text { Reduced and altered due } \\
\text { to dense occupation by } \\
\text { isolated residences and } \\
\text { housing units as well as } \\
\text { invasions on lands of the } \\
\text { estuary. }\end{array}$ \\
\hline Reef barrier & Absent & Present & Present & Present & Absent & Absent \\
\hline $\begin{array}{l}\text { Type of } \\
\text { sediment }\end{array}$ & - & $\begin{array}{l}\text { Muddy, resulting } \\
\text { from river-ocean } \\
\text { sedimentation. }\end{array}$ & - & Quartz sand and mud. & $\begin{array}{l}\text { Muddy, rich in organic } \\
\text { matter. }\end{array}$ & - \\
\hline Human actions & $\begin{array}{l}\text { Release of } \\
\text { pollutants by } \\
\text { industries in the } \\
\text { hydrographic } \\
\text { basin; shrimp } \\
\text { farming. }\end{array}$ & $\begin{array}{l}\text { Polluting action of } \\
\text { products used in } \\
\text { sugarcane } \\
\text { cultivation and } \\
\text { poultry farming, } \\
\text { domestic and } \\
\text { industrial waste; } \\
\text { mineral } \\
\text { extraction; } \\
\text { shrimp farming. }\end{array}$ & $\begin{array}{l}\text { Property lots; } \\
\text { shrimp farming. }\end{array}$ & $\begin{array}{l}\text { Despite the pollution of } \\
\text { the estuaries of the } \\
\text { Botafogo and Igarassu } \\
\text { Rivers by industrial and } \\
\text { urban waste, the continual } \\
\text { movement of the waters } \\
\text { through the north and } \\
\text { south sandbanks provides } \\
\text { periodic renewal of the } \\
\text { waters of this ecosystem. }\end{array}$ & $\begin{array}{l}\text { Devastation of vegetal } \\
\text { coverage, pollution from } \\
\text { trash and domestic } \\
\text { sewage, industrial waste } \\
\text { released directly into the } \\
\text { rivers, causing the death } \\
\text { of fish and crustaceans, } \\
\text { temporary disappearance } \\
\text { of crabs, atrophy of } \\
\text { oysters and mussels; trash } \\
\text { dumps; waste from } \\
\text { poultry slaughterhouse. }\end{array}$ & $\begin{array}{l}\text { Waste from pig and } \\
\text { poultry farms; pollution } \\
\text { from domestic and } \\
\text { industrial waste (poultry } \\
\text { slaughterhouse and textile } \\
\text { industries); occupation of } \\
\text { areas by property lots and } \\
\text { housing units. }\end{array}$ \\
\hline
\end{tabular}




\begin{tabular}{|c|c|c|c|c|c|c|}
\hline $\begin{array}{l}\text { Physiographic } \\
\text { factors }\end{array}$ & $\begin{array}{l}\text { Beberibe } \\
\text { River }\end{array}$ & $\begin{array}{l}\text { Capibaribe } \\
\text { River }\end{array}$ & $\begin{array}{l}\text { Jaboatão and } \\
\text { Pirapama Rivers }\end{array}$ & $\begin{array}{l}\text { Suape Estuary } \\
\text { Complex }\end{array}$ & $\begin{array}{l}\text { Maracaípe } \\
\text { River }\end{array}$ & $\begin{array}{l}\text { Sirinhaém } \\
\text { River }\end{array}$ \\
\hline Area & $108 \mathrm{Km}^{2}$ & $7716 \mathrm{Km}^{2}$ & $1002.3 \mathrm{Km}^{2}$ & - & - & - \\
\hline $\begin{array}{l}\text { Estuary } \\
\text { characteristics }\end{array}$ & $\begin{array}{l}\text { Completely } \\
\text { altered. }\end{array}$ & $\begin{array}{l}\text { Anoxic zones } \\
\text { throughout nearly } \\
\text { the entire estuary } \\
\text { in both surface } \\
\text { and deep layers } \\
\text { stemming from } \\
\text { industrial and } \\
\text { urban waste. }\end{array}$ & $\begin{array}{l}\text { Degree of pollution } \\
\text { of the Jaboatão } \\
\text { River is often quite } \\
\text { high, } \\
\text { compromising } \\
\text { water quality of the } \\
\text { Barra das Jangadas } \\
\text { Beach. }\end{array}$ & $\begin{array}{l}\text { Suape area } \\
\text { encompasses } \\
\text { estuaries of the } \\
\text { Massangana, } \\
\text { Tatuoca, Ipojuca } \\
\text { and Merepe } \\
\text { Rivers. }\end{array}$ & - & - \\
\hline Reef barrier & Absent & Absent & Present & Present & Present & Present \\
\hline Type of sediment & - & - & - & - & - & - \\
\hline Human actions & $\begin{array}{l}\text { Landfills, } \\
\text { housing and } \\
\text { roads. }\end{array}$ & $\begin{array}{l}\text { Landfills of flood } \\
\text { areas and real } \\
\text { estate expansion. }\end{array}$ & $\begin{array}{l}\text { Release of } \\
\text { domestic and } \\
\text { industrial waste. }\end{array}$ & $\begin{array}{l}\text { Pollution from } \\
\text { agro-industrial } \\
\text { activity (plants, } \\
\text { distilleries and } \\
\text { sugarcane } \\
\text { cultivation). }\end{array}$ & - & $\begin{array}{l}\text { High amount } \\
\text { of domestic } \\
\text { and industrial } \\
\text { waste. }\end{array}$ \\
\hline
\end{tabular}




\begin{tabular}{|c|c|c|c|c|c|}
\hline Physiographic factors & Formoso River & $\begin{array}{l}\text { Ilhetas and } \\
\text { Mamucabas } \\
\text { Rivers }\end{array}$ & Una River & $\begin{array}{l}\text { Meireles } \\
\text { Stream }\end{array}$ & $\begin{array}{l}\text { Persinunga } \\
\text { River }\end{array}$ \\
\hline Area (ha) & 2724 & 402 & 533 & - & - \\
\hline Estuary characteristics & $\begin{array}{l}\text { Protection of reefs } \\
\text { at the mouth of the } \\
\text { estuary, low tide } \\
\text { amplitude and } \\
\text { small liquid } \\
\text { discharge. }\end{array}$ & $\begin{array}{l}\text { Formed by a } \\
\text { floodplain covered } \\
\text { with mangrove } \\
\text { vegetation } \\
\text { throughout its } \\
\text { length; surrounded } \\
\text { by large areas of } \\
\text { forest; a sandbar } \\
\text { delimits its lower } \\
\text { stretch. }\end{array}$ & $\begin{array}{l}\text { Margins with large areas of } \\
\text { mangrove vegetation. }\end{array}$ & - & - \\
\hline Reef barrier & Present & Present & Absent & Present & Present \\
\hline Type of sediment & Sandy-muddy & - & - & - & - \\
\hline Human actions & $\begin{array}{l}\text { Domestic waste, } \\
\text { landfills, } \\
\text { destruction of part } \\
\text { of remaining } \\
\text { Atlantic forest, } \\
\text { tourism expansion, } \\
\text { trash dumps. }\end{array}$ & - & $\begin{array}{l}\text { Pollution from agro- } \\
\text { industrial activity (plants, } \\
\text { distilleries and sugarcane } \\
\text { cultivation). }\end{array}$ & - & - \\
\hline
\end{tabular}


APPENDIX II - Valid names for estuarine species occurring in Pernambuco, respective occupation status and association to reefs (Reed Assoc.) GM - Estuary of the Goiana and Megaó Rivers; I - Estuary of Itapessoca River; J - Estuary of the Jaguaribe River; IEC - Itamaracá Estuary Complex; T - Estuary of the Timbó River; B - Estuary of the Beberibe River; C - Estuary of the Capibaribe River; JP - Estuary of the Jaboatão and Pirapama Rivers; SEC - Suape Estuary Complex; F - Estuary of the Formoso River; IM - Estuaries of the Ilhetas and Mamucabas Rivers; $U$ - Estuary of the Una River.

\begin{tabular}{|c|c|c|c|c|c|c|c|c|c|c|c|c|c|c|}
\hline VALID NAMES & NAMES CITED & $\begin{array}{c}\text { Reef } \\
\text { Assoc. }\end{array}$ & GM & $\mathbf{I}$ & $\mathbf{J}$ & IEC & $\mathbf{T}$ & B & $\mathbf{C}$ & JP & SEC & $\mathbf{F}$ & IM & $\mathbf{U}$ \\
\hline Abudefduf saxatilis (Linnaeus, 1758) & & $\mathrm{X}$ & 0 & 0 & 0 & 1 & 0 & 0 & 0 & 0 & 1 & 0 & 0 & 0 \\
\hline Acanthurus bahianus Castelnau, 1855 & & $\mathrm{x}$ & 0 & 0 & 0 & 1 & 0 & 0 & 0 & 0 & 1 & 0 & 0 & 0 \\
\hline Acanthurus chirurgus (Bloch, 1787) & & $\mathrm{x}$ & 0 & 0 & 0 & 1 & 0 & 0 & 0 & 0 & 0 & 1 & 0 & 0 \\
\hline Achirus achirus (Linnaeus, 1758) & & & 0 & 0 & 0 & 1 & 0 & 0 & 0 & 0 & 0 & 0 & 0 & 0 \\
\hline Achirus declivis Chabanaud, 1940 & & & 0 & 0 & 0 & 1 & 0 & 0 & 0 & 0 & 0 & 1 & 0 & 0 \\
\hline Achirus lineatus (Linnaeus, 1758) & & & 1 & 1 & 1 & 1 & 0 & 0 & 0 & 0 & 0 & 1 & 0 & 0 \\
\hline Albula vulpes (Linnaeus, 1758) & & $x$ & 0 & 0 & 1 & 1 & 0 & 0 & 0 & 0 & 1 & 1 & 0 & 0 \\
\hline Aluterus schoepfii (Walbaum, 1792) & Alutera schoepfii & $x$ & 0 & 0 & 0 & 1 & 0 & 0 & 0 & 0 & 0 & 0 & 0 & 0 \\
\hline
\end{tabular}




\begin{tabular}{|c|c|c|c|c|c|c|c|c|c|c|c|c|c|c|}
\hline VALID NAMES & NAMES CITED & $\begin{array}{c}\text { Reef } \\
\text { Assoc. }\end{array}$ & $\mathbf{G M}$ & $\mathbf{I}$ & J & IEC & $\mathbf{T}$ & B & C & JP & SEC & $F$ & IM & $\mathbf{U}$ \\
\hline $\begin{array}{l}\text { Amphichthys cryptocentrus Valenciennes, } \\
\text { 1837) }\end{array}$ & & & 0 & 0 & 0 & 1 & 0 & 0 & 0 & 0 & 0 & 0 & 0 & 0 \\
\hline Anchoa filifera (Fowler, 1915) & & & 0 & 0 & 0 & 1 & 0 & 0 & 0 & 0 & 0 & 0 & 0 & 0 \\
\hline Anchoa januaria (Steindachner, 1879) & & & 0 & 0 & 0 & 1 & 0 & 0 & 0 & 0 & 0 & 0 & 0 & 0 \\
\hline $\begin{array}{l}\text { Anchoa lyolepis (Evermann \& Marsh, } \\
\text { 1900). }\end{array}$ & & $x$ & 0 & 1 & 0 & 0 & 0 & 0 & 0 & 0 & 0 & 0 & 0 & 0 \\
\hline Anchoa tricolor (Spix \& Agassiz, 1829) & & & 0 & 0 & 0 & 1 & 0 & 0 & 0 & 0 & 0 & 1 & 0 & 0 \\
\hline Anchovia clupeoides (Swainson, 1839) & & & 1 & 0 & 1 & 1 & 0 & 0 & 0 & 0 & 1 & 1 & 0 & 0 \\
\hline Anchoviella lepidentostole (Fowler, 1911). & & & 0 & 1 & 1 & 0 & 0 & 0 & 0 & 0 & 0 & 0 & 0 & 0 \\
\hline Anisotremus virginicus (Linnaeus, 1758) & & $X$ & 0 & 0 & 0 & 1 & 0 & 0 & 0 & 0 & 0 & 0 & 1 & 0 \\
\hline Antennarius striatus (Shaw, 1794) & $\begin{array}{l}\text { Antenarius scaber; } \\
\text { Phrynelox scaber }\end{array}$ & $X$ & 0 & 0 & 0 & 1 & 0 & 0 & 0 & 0 & 0 & 1 & 0 & 0 \\
\hline Apogon maculatus (Poey, 1860) & & $X$ & 0 & 0 & 0 & 0 & 0 & 0 & 0 & 0 & 1 & 0 & 0 & 0 \\
\hline $\begin{array}{l}\text { Archosargus probatocephalus (Walbaum, } \\
\text { 1792) }\end{array}$ & & $x$ & 0 & 0 & 0 & 0 & 0 & 0 & 0 & 0 & 0 & 1 & 0 & 0 \\
\hline
\end{tabular}




\begin{tabular}{|c|c|c|c|c|c|c|c|c|c|c|c|c|c|c|}
\hline VALID NAMES & NAMES CITED & $\begin{array}{l}\text { Reef. } \\
\text { Assoc. }\end{array}$ & $\mathbf{G M}$ & $\mathbf{I}$ & J & IEC & $\mathbf{T}$ & B & C & JP & SEC & $\mathbf{F}$ & IM & $\mathbf{U}$ \\
\hline Archosargus rhomboidalis (Linnaeus, 1758) & $\begin{array}{l}\text { Archosargus } \\
\text { unimaculatus }\end{array}$ & $X$ & 0 & 0 & 1 & 1 & 0 & 0 & 0 & 0 & 0 & 1 & 0 & 0 \\
\hline Aspistor luniscutis (Valenciennes, 1840) & Arius luniscutis & & 1 & 0 & 0 & 0 & 0 & 0 & 0 & 0 & 0 & 0 & 0 & 0 \\
\hline Aspistor parkeri (Traill, 1832) & Arius parkeri & & 1 & 0 & 0 & 1 & 0 & 0 & 0 & 0 & 0 & 0 & 0 & 0 \\
\hline Astyanax bimaculatus (Linnaeus, 1758) & $\begin{array}{l}\text { Astyanax bimaculatus } \\
\text { vittatus }\end{array}$ & & 0 & 0 & 0 & 0 & 0 & 0 & 0 & 1 & 0 & 0 & 1 & 0 \\
\hline $\begin{array}{l}\text { Atherinella brasiliensis (Quoy \& Gaimard, } \\
\text { 1825) }\end{array}$ & $\begin{array}{l}\text { Xenomelaniris } \\
\text { brasiliensis }\end{array}$ & & 1 & 1 & 1 & 1 & 1 & 0 & 0 & 0 & 1 & 1 & 0 & 0 \\
\hline Bagre marinus (Mitchill, 1815) & & & 0 & 0 & 0 & 1 & 0 & 0 & 0 & 0 & 0 & 0 & 0 & 0 \\
\hline Bairdiella ronchus (Cuvier, 1830) & & & 1 & 0 & 1 & 1 & 0 & 0 & 0 & 0 & 0 & 1 & 0 & 0 \\
\hline $\begin{array}{l}\text { Bathygobius soporator (Valenciennes, } \\
\text { 1837) }\end{array}$ & & & 1 & 1 & 1 & 1 & 0 & 0 & 0 & 1 & 1 & 1 & 1 & 0 \\
\hline Bothus ocellatus (Agassiz, 1831) & & $x$ & 0 & 1 & 0 & 1 & 0 & 0 & 0 & 0 & 0 & 0 & 0 & 0 \\
\hline Bryx dunckeri (Metzelaar, 1919). & Syngnathus dunckeri & & 0 & 1 & 0 & 0 & 0 & 0 & 0 & 0 & 0 & 0 & 0 & 0 \\
\hline Cantherhines pullus (Ranzani, 1842) & Amanses pullus & $X$ & 0 & 0 & 0 & 1 & 0 & 0 & 0 & 0 & 0 & 0 & 0 & 0 \\
\hline
\end{tabular}




\begin{tabular}{|c|c|c|c|c|c|c|c|c|c|c|c|c|c|c|}
\hline VALID NAMES & NAMES CITED & $\begin{array}{l}\text { Reef. } \\
\text { Assoc. }\end{array}$ & $\mathbf{G M}$ & $\mathbf{I}$ & J & IEC & $\mathbf{T}$ & B & C & JP & SEC & $F$ & IM & $\mathbf{U}$ \\
\hline $\begin{array}{l}\text { Canthigaster figuereidoi Moura \& Castro, } \\
2002\end{array}$ & $\begin{array}{l}\text { Canthigaster } \\
\text { rostrata; C. rostratus }\end{array}$ & $x$ & 0 & 0 & 0 & 1 & 0 & 0 & 0 & 0 & 0 & 0 & 0 & 0 \\
\hline Carangoides bartholomaei (Cuvier, 1833) & & $X$ & 0 & 0 & 0 & 0 & 0 & 0 & 0 & 0 & 1 & 1 & 0 & 0 \\
\hline Carangoides crysos (Mitchill, 1815) & Caranx crysos & $x$ & 0 & 0 & 1 & 0 & 0 & 0 & 0 & 0 & 0 & 1 & 0 & 0 \\
\hline Caranx hippos (Linnaeus, 1766) & & $x$ & 0 & 0 & 1 & 1 & 0 & 0 & 0 & 0 & 0 & 0 & 0 & 0 \\
\hline Caranx latusAgassiz, 1831 & & $x$ & 1 & 0 & 1 & 0 & 1 & 0 & 0 & 0 & 1 & 1 & 1 & 0 \\
\hline $\begin{array}{l}\text { Cathorops agassizii (Eigenmann \& } \\
\text { Eigenmann, 1888) }\end{array}$ & Cathorops pleurops & & 1 & 0 & 0 & 0 & 0 & 0 & 0 & 0 & 0 & 0 & 0 & 0 \\
\hline Cathorops spixii (Agassiz, 1829) & & & 1 & 0 & 1 & 1 & 0 & 0 & 0 & 0 & 0 & 0 & 0 & 0 \\
\hline Centropomus parallelus Poey, 1860 & & & 0 & 1 & 1 & 1 & 0 & 0 & 0 & 0 & 0 & 1 & 0 & 0 \\
\hline Centropomus pectinatus Poey, 1860 & & & 1 & 0 & 0 & 0 & 0 & 0 & 0 & 0 & 0 & 1 & 0 & 0 \\
\hline Centropomus undecimalis (Bloch, 1792) & & $x$ & 1 & 1 & 1 & 1 & 0 & 0 & 0 & 1 & 0 & 1 & 1 & 0 \\
\hline Centropomus mexicanus Bocourt, 1868 & & & 1 & 0 & 0 & 0 & 0 & 0 & 0 & 0 & 0 & 0 & 0 & 0 \\
\hline
\end{tabular}




\begin{tabular}{|c|c|c|c|c|c|c|c|c|c|c|c|c|c|c|}
\hline VALID NAMES & NAMES CITED & $\begin{array}{l}\text { Reef. } \\
\text { Assoc. }\end{array}$ & $\mathbf{G M}$ & $\mathbf{I}$ & J & IEC & $\mathbf{T}$ & B & $\mathbf{C}$ & JP & SEC & $\mathbf{F}$ & IM & $\mathbf{U}$ \\
\hline Cetengraulis edentulus (Cuvier, 1829) & & & 1 & 0 & 0 & 1 & 0 & 0 & 0 & 0 & 1 & 1 & 0 & 0 \\
\hline Chaetodipterus faber (Broussonet, 1782) & & $\mathrm{X}$ & 1 & 1 & 1 & 1 & 0 & 0 & 0 & 0 & 1 & 1 & 1 & 0 \\
\hline Chaetodon ocellatus Bloch, 1787 & & $X$ & 0 & 0 & 0 & 1 & 0 & 0 & 0 & 0 & 0 & 0 & 0 & 0 \\
\hline Chaetodon striatus Linnaeus, 1758 & & $\mathrm{X}$ & 0 & 0 & 0 & 1 & 0 & 0 & 0 & 0 & 0 & 0 & 0 & 0 \\
\hline $\begin{array}{l}\text { Chloroscombrus chrysurus (Linnaeus, } \\
1766 \text { ) }\end{array}$ & & $\mathrm{x}$ & 0 & 0 & 0 & 1 & 1 & 0 & 0 & 0 & 0 & 1 & 1 & 0 \\
\hline $\begin{array}{l}\text { Citharichthys arenaceus Evermann \& } \\
\text { Marsh, } 1900\end{array}$ & & $X$ & 1 & 0 & 1 & 0 & 0 & 0 & 0 & 0 & 0 & 1 & 0 & 0 \\
\hline Citharichthys macrops Dresel, 1885 & & $\mathrm{X}$ & 0 & 1 & 0 & 0 & 0 & 0 & 0 & 0 & 0 & 0 & 0 & 0 \\
\hline Citharichthys spilopterus Günther, 1862 & & & 1 & 0 & 0 & 1 & 1 & 1 & 0 & 1 & 1 & 1 & 1 & 0 \\
\hline $\begin{array}{l}\text { Colomesus psittacus (Bloch \& Schneider, } \\
\text { 1801) }\end{array}$ & & & 1 & 0 & 0 & 1 & 0 & 0 & 0 & 0 & 0 & 0 & 0 & 0 \\
\hline $\begin{array}{l}\text { Colomesus asellus (Müller \& Troschel, } \\
\text { 1849) }\end{array}$ & & & 0 & 0 & 1 & 0 & 0 & 0 & 0 & 0 & 0 & 0 & 0 & 0 \\
\hline Cosmocampus elucens (Poey, 1868) & Syngnathus elucens & $\mathrm{X}$ & 0 & 1 & 1 & 1 & 0 & 0 & 0 & 0 & 1 & 0 & 0 & 0 \\
\hline
\end{tabular}




\begin{tabular}{|c|c|c|c|c|c|c|c|c|c|c|c|c|c|c|}
\hline VALID NAMES & NAMES CITED & $\begin{array}{l}\text { Reef. } \\
\text { Assoc. }\end{array}$ & GM & $\mathbf{I}$ & J & IEC & $\mathbf{T}$ & $\mathbf{B}$ & $\mathbf{C}$ & JP & SEC & $\mathbf{F}$ & IM & $\mathbf{U}$ \\
\hline Crenicichla saxatilis (Linnaeus, 1758) & & & 0 & 0 & 0 & 0 & 0 & 0 & 0 & 0 & 0 & 0 & 1 & 0 \\
\hline $\begin{array}{l}\text { Ctenogobius boleosoma (Jordan \& Gilbert, } \\
\text { 1882) }\end{array}$ & $\begin{array}{l}\text { Gobionellus } \\
\text { boleosoma }\end{array}$ & & 0 & 1 & 1 & 1 & 0 & 0 & 0 & 1 & 0 & 0 & 1 & 0 \\
\hline $\begin{array}{l}\text { Ctenogobius smaragdus (Valenciennes, } \\
\text { 1837) }\end{array}$ & $\begin{array}{l}\text { Gobionellus } \\
\text { smaragdus }\end{array}$ & & 0 & 0 & 1 & 1 & 0 & 0 & 0 & 0 & 1 & 1 & 0 & 0 \\
\hline Ctenogobius stigmaticus (Poey, 1860) & $\begin{array}{l}\text { Gobionellus } \\
\text { stigmaticus }\end{array}$ & & 0 & 0 & 0 & 1 & 0 & 0 & 0 & 0 & 0 & 0 & 0 & 0 \\
\hline $\begin{array}{l}\text { Cyclichthys antillarum (Jordan \& Rutter, } \\
\text { 1897) }\end{array}$ & $\begin{array}{l}\text { Chilomycterus } \\
\text { antillarum }\end{array}$ & $X$ & 0 & 0 & 0 & 0 & 0 & 0 & 0 & 0 & 0 & 1 & 0 & 0 \\
\hline Cyclichthys spinosus (Linnaeus, 1758) & $\begin{array}{l}\text { Chilomycterus } \\
\text { spinosus }\end{array}$ & & 0 & 0 & 1 & 1 & 0 & 0 & 0 & 0 & 0 & 0 & 0 & 0 \\
\hline Cynoponticus savanna (Bancroft, 1831) & & & 0 & 0 & 0 & 1 & 0 & 0 & 0 & 0 & 0 & 0 & 0 & 0 \\
\hline Cynoscion acoupa (Lacepède, 1801) & & & 1 & 0 & 0 & 1 & 0 & 0 & 0 & 0 & 0 & 0 & 0 & 0 \\
\hline Cynoscion leiarchus (Cuvier, 1830) & & & 0 & 0 & 0 & 1 & 0 & 0 & 0 & 0 & 0 & 1 & 0 & 0 \\
\hline Dactylopterus volitans (Linnaeus, 1758) & & $\mathrm{X}$ & 1 & 0 & 1 & 1 & 0 & 0 & 0 & 0 & 0 & 1 & 1 & 0 \\
\hline
\end{tabular}




\begin{tabular}{|c|c|c|c|c|c|c|c|c|c|c|c|c|c|c|}
\hline VALID NAMES & NAMES CITED & $\begin{array}{l}\text { Reef. } \\
\text { Assoc. }\end{array}$ & GM & $\mathbf{I}$ & $\mathbf{J}$ & IEC & $\mathbf{T}$ & B & $\mathbf{C}$ & JP & SEC & $\mathbf{F}$ & IM & $\mathbf{U}$ \\
\hline Dasyatis guttata (Bloch \& Schneider, 1801) & & & 0 & 0 & 1 & 1 & 0 & 0 & 0 & 0 & 0 & 1 & 1 & 0 \\
\hline Diapterus auratus Ranzani, 1842 & $\begin{array}{l}\text { Diapterus } \\
\text { olisthostomus }\end{array}$ & & 0 & 0 & 1 & 1 & 0 & 0 & 0 & 1 & 0 & 1 & 1 & 0 \\
\hline Diapterus rhombeus (Cuvier, 1829) & & & 0 & 1 & 1 & 1 & 1 & 0 & 0 & 1 & 1 & 1 & 0 & 0 \\
\hline Diodon holocanthus Linnaeus, 1758 & & $X$ & 0 & 0 & 0 & 1 & 0 & 0 & 0 & 0 & 0 & 0 & 0 & 0 \\
\hline Diodon hystrix Linnaeus, 1758 & & $X$ & 0 & 0 & 0 & 1 & 0 & 0 & 0 & 0 & 0 & 0 & 0 & 0 \\
\hline $\begin{array}{l}\text { Diplectrum radiale (Quoy \& Gaimard, } \\
1824 \text { ) }\end{array}$ & & $x$ & 0 & 0 & 0 & 0 & 0 & 0 & 0 & 0 & 1 & 0 & 0 & 0 \\
\hline Dormitator maculatus (Bloch, 1792) & & & 1 & 0 & 1 & 1 & 0 & 0 & 0 & 1 & 0 & 1 & 1 & 0 \\
\hline Echeneis naucrates Linnaeus, 1758 & & $X$ & 0 & 0 & 0 & 1 & 0 & 0 & 0 & 0 & 0 & 0 & 0 & 0 \\
\hline Eleotris pisonis (Gmelin, 1789) & & & 1 & 0 & 0 & 1 & 0 & 0 & 0 & 0 & 0 & 1 & 1 & 0 \\
\hline Elops saurus Linnaeus, 1766 & & $x$ & 0 & 1 & 1 & 1 & 0 & 0 & 0 & 0 & 0 & 1 & 0 & 0 \\
\hline Entomacrodus nigricans Gill, 1859 & & $x$ & 0 & 0 & 0 & 0 & 0 & 0 & 0 & 0 & 1 & 0 & 0 & 0 \\
\hline Epinephelus itajara (Lichtenstein, 1822) & & $\mathrm{X}$ & 0 & 0 & 0 & 1 & 0 & 0 & 0 & 0 & 0 & 1 & 0 & 0 \\
\hline
\end{tabular}




\begin{tabular}{|c|c|c|c|c|c|c|c|c|c|c|c|c|c|c|}
\hline VALID NAMES & NAMES CITED & $\begin{array}{l}\text { Reef. } \\
\text { Assoc. }\end{array}$ & GM & $\mathbf{I}$ & J & IEC & $\mathbf{T}$ & B & $\mathbf{C}$ & JP & SEC & $\mathbf{F}$ & IM & $\mathbf{U}$ \\
\hline Erotelis smaragdus (Valenciennes, 1837) & & & 1 & 0 & 0 & 1 & 0 & 0 & 0 & 0 & 1 & 0 & 0 & 0 \\
\hline Etropus crossotus Jordan \& Gilbert, 1882 & $\begin{array}{l}\text { Citharichthys } \\
\text { crossotus }\end{array}$ & & 0 & 0 & 0 & 1 & 0 & 0 & 0 & 0 & 0 & 1 & 0 & 0 \\
\hline $\begin{array}{l}\text { Eucinostomus argenteus Baird \& Girard, } \\
1855\end{array}$ & & & 1 & 1 & 1 & 1 & 1 & 0 & 0 & 0 & 1 & 1 & 0 & 0 \\
\hline $\begin{array}{l}\text { Eucinostomus gula (Quoy \& Gaimard, } \\
\text { 1824) }\end{array}$ & Gerres gula & $\mathrm{X}$ & 0 & 1 & 1 & 1 & 0 & 0 & 0 & 1 & 0 & 1 & 0 & 0 \\
\hline Eucinostomus havana (Nichols, 1912) & & $\mathrm{X}$ & 0 & 0 & 0 & 1 & 1 & 0 & 0 & 0 & 0 & 0 & 1 & 0 \\
\hline Eucinostomus lefroyi (Goode, 1874) & Ulaema lefroyi & $X$ & 0 & 0 & 1 & 1 & 1 & 0 & 0 & 0 & 1 & 1 & 0 & 0 \\
\hline $\begin{array}{l}\text { Eucinostomus melanopterus (Bleeker, } \\
\text { 1863) }\end{array}$ & & $\mathrm{X}$ & 1 & 1 & 1 & 1 & 0 & 0 & 0 & 1 & 1 & 1 & 0 & 0 \\
\hline Eugerres brasilianus (Cuvier, 1830) & & $\mathrm{X}$ & 1 & 1 & 1 & 1 & 1 & 0 & 0 & 1 & 0 & 1 & 0 & 0 \\
\hline Evorthodus lyricus (Girard, 1858) & & & 0 & 0 & 0 & 1 & 0 & 0 & 0 & 0 & 0 & 0 & 0 & 0 \\
\hline Fistularia petimba Lacepède, 1803 & & $X$ & 0 & 0 & 1 & 0 & 0 & 0 & 0 & 0 & 0 & 1 & 0 & 0 \\
\hline Fistularia tabacaria Linnaeus, 1758 & & $x$ & 0 & 0 & 1 & 1 & 0 & 0 & 0 & 0 & 1 & 0 & 0 & 0 \\
\hline
\end{tabular}




\begin{tabular}{|c|c|c|c|c|c|c|c|c|c|c|c|c|c|c|}
\hline VALID NAMES & NAMES CITED & $\begin{array}{l}\text { Reef. } \\
\text { Assoc. }\end{array}$ & $\mathbf{G M}$ & $\mathbf{I}$ & $\mathbf{J}$ & IEC & $\mathbf{T}$ & B & C & JP & SEC & $\mathbf{F}$ & IM & $\mathbf{U}$ \\
\hline Genyatremus luteus (Bloch, 1790) & & & 0 & 0 & 0 & 1 & 0 & 0 & 0 & 0 & 0 & 1 & 0 & 0 \\
\hline Gerres cinereus (Walbaum, 1792) & & $X$ & 0 & 0 & 0 & 1 & 0 & 0 & 0 & 0 & 0 & 1 & 0 & 0 \\
\hline Gobionellus oceanicus (Pallas, 1770) & & & 1 & 0 & 1 & 1 & 0 & 0 & 0 & 1 & 1 & 1 & 1 & 0 \\
\hline Gobionellus stomatus Starks, 1913 & & & 0 & 0 & 1 & 1 & 0 & 0 & 0 & 0 & 0 & 1 & 0 & 0 \\
\hline Guavina guavina (Valenciennes, 1837) & & & 1 & 1 & 1 & 1 & 0 & 0 & 1 & 0 & 0 & 1 & 0 & 0 \\
\hline Gymnothorax funebris Ranzani, 1839 & Lycodontis funebris & $x$ & 1 & 0 & 1 & 1 & 0 & 0 & 0 & 0 & 0 & 1 & 0 & 0 \\
\hline Gymnothorax moringa (Cuvier, 1829) & Lycodontis moringa & $X$ & 0 & 0 & 0 & 1 & 0 & 0 & 0 & 0 & 1 & 0 & 0 & 0 \\
\hline $\begin{array}{l}\text { Gymnothorax nigromarginatus (Girard, } \\
1858 \text { ) }\end{array}$ & & $x$ & 0 & 0 & 0 & 1 & 0 & 0 & 0 & 0 & 0 & 0 & 0 & 0 \\
\hline Gymnothorax ocellatus Agassiz, 1831 & & & 0 & 0 & 0 & 0 & 0 & 0 & 0 & 0 & 0 & 1 & 0 & 0 \\
\hline Haemulon aurolineatum Cuvier, 1830 & & $x$ & 0 & 0 & 0 & 1 & 0 & 0 & 0 & 0 & 0 & 0 & 0 & 0 \\
\hline $\begin{array}{l}\text { Haemulon flavolineatum (Desmarest, } \\
\text { 1823) }\end{array}$ & & $x$ & 0 & 0 & 0 & 0 & 0 & 0 & 0 & 0 & 1 & 0 & 0 & 0 \\
\hline Haemulon parra (Desmarest, 1823) & & $X$ & 0 & 0 & 0 & 1 & 1 & 0 & 1 & 0 & 0 & 1 & 1 & 0 \\
\hline
\end{tabular}




\begin{tabular}{|c|c|c|c|c|c|c|c|c|c|c|c|c|c|c|}
\hline VALID NAMES & NAMES CITED & $\begin{array}{l}\text { Reef. } \\
\text { Assoc. }\end{array}$ & GM & $\mathbf{I}$ & $\mathbf{J}$ & IEC & $\mathbf{T}$ & $\mathbf{B}$ & $\mathbf{C}$ & JP & SEC & $\mathbf{F}$ & IM & $\mathbf{U}$ \\
\hline Haemulon plumierii (Lacepède, 1801) & & $\mathrm{X}$ & 0 & 0 & 0 & 0 & 0 & 0 & 0 & 0 & 1 & 0 & 0 & 0 \\
\hline $\begin{array}{l}\text { Haemulon steindachneri (Jordan \& } \\
\text { Gilbert, 1882) }\end{array}$ & & $\mathrm{X}$ & 0 & 0 & 1 & 0 & 0 & 0 & 0 & 0 & 0 & 0 & 0 & 0 \\
\hline Harengula clupeola (Cuvier, 1829) & & $\mathrm{X}$ & 0 & 1 & 1 & 1 & 1 & 0 & 0 & 0 & 0 & 1 & 0 & 1 \\
\hline Harengula jaguana Poey, 1865 & Harengula pensacolae & & 0 & 0 & 0 & 0 & 0 & 0 & 0 & 0 & 1 & 0 & 0 & 0 \\
\hline Hemiramphus balao Lesueur, 1821 & & $x$ & 0 & 0 & 0 & 0 & 0 & 0 & 0 & 0 & 0 & 1 & 0 & 0 \\
\hline Hemiramphus brasiliensis (Linnaeus, 1758) & & $x$ & 0 & 0 & 0 & 1 & 0 & 0 & 0 & 0 & 0 & 0 & 0 & 0 \\
\hline Hippocampus reidi Ginsburg, 1933 & & $\mathrm{X}$ & 0 & 1 & 0 & 1 & 0 & 0 & 0 & 0 & 0 & 1 & 0 & 0 \\
\hline Hirundichthys affinis (Günther, 1866) & & & 0 & 0 & 0 & 0 & 0 & 0 & 0 & 0 & 0 & 1 & 0 & 0 \\
\hline Histrio histrio (Linnaeus, 1758) & & $X$ & 0 & 0 & 0 & 0 & 0 & 0 & 0 & 0 & 0 & 1 & 0 & 0 \\
\hline Holocentrus adscensionis (Osbeck, 1765) & & $X$ & 0 & 0 & 0 & 0 & 0 & 0 & 0 & 0 & 1 & 0 & 0 & 0 \\
\hline Hoplias malabaricus (Bloch, 1794) & & & 0 & 0 & 0 & 0 & 0 & 0 & 0 & 0 & 0 & 0 & 1 & 1 \\
\hline $\begin{array}{l}\text { Hyporhamphus roberti roberti } \\
\text { (Valenciennes, 1847) }\end{array}$ & & & 0 & 0 & 1 & 1 & 0 & 0 & 0 & 0 & 1 & 1 & 0 & 0 \\
\hline
\end{tabular}




\begin{tabular}{|c|c|c|c|c|c|c|c|c|c|c|c|c|c|c|}
\hline VALID NAMES & NAMES CITED & $\begin{array}{l}\text { Reef. } \\
\text { Assoc. }\end{array}$ & $\mathbf{G M}$ & $\mathbf{I}$ & $\mathbf{J}$ & IEC & $\mathbf{T}$ & B & $\mathbf{C}$ & JP & SEC & $\mathbf{F}$ & IM & $\mathbf{U}$ \\
\hline $\begin{array}{l}\text { Hyporhamphus unifasciatus (Ranzani, } \\
\text { 1841) }\end{array}$ & & $\mathrm{X}$ & 1 & 1 & 1 & 1 & 0 & 0 & 0 & 0 & 0 & 1 & 1 & 0 \\
\hline Hypostomus plecostomus (Linnaeus, 1758) & $\begin{array}{l}\text { Plecostomus } \\
\text { plecostomus }\end{array}$ & & 0 & 0 & 0 & 0 & 0 & 0 & 0 & 0 & 0 & 0 & 0 & 1 \\
\hline $\begin{array}{l}\text { Labrisomus nuchipinnis (Quoy \& Gaimard, } \\
\text { 1824) }\end{array}$ & & $x$ & 0 & 1 & 0 & 0 & 0 & 0 & 0 & 0 & 1 & 0 & 0 & 0 \\
\hline Lactophrys trigonus (Linnaeus, 1758) & & $X$ & 0 & 0 & 0 & 1 & 1 & 0 & 0 & 0 & 0 & 1 & 0 & 0 \\
\hline Lactophrys triqueter (Linnaeus, 1758) & & $x$ & 0 & 0 & 0 & 1 & 0 & 0 & 0 & 0 & 0 & 1 & 0 & 0 \\
\hline Lagocephalus laevigatus (Linnaeus, 1766) & & & 0 & 0 & 1 & 1 & 0 & 0 & 0 & 0 & 0 & 1 & 0 & 0 \\
\hline $\begin{array}{l}\text { Lile piquitinga (Schreiner \& Miranda } \\
\text { Ribeiro, 1903) }\end{array}$ & & & 0 & 1 & 1 & 1 & 1 & 0 & 1 & 1 & 0 & 1 & 0 & 0 \\
\hline Lobotes surinamensis (Bloch, 1790) & & $x$ & 0 & 0 & 0 & 1 & 0 & 0 & 0 & 0 & 0 & 1 & 0 & 0 \\
\hline $\begin{array}{l}\text { Lutjanus alexandrei Moura \& Lindemam, } \\
2007\end{array}$ & & & 0 & 0 & 1 & 0 & 0 & 0 & 0 & 0 & 0 & 0 & 0 & 0 \\
\hline Lutjanus analis (Cuvier, 1828) & & $x$ & 0 & 1 & 0 & 1 & 0 & 0 & 0 & 0 & 0 & 1 & 0 & 0 \\
\hline
\end{tabular}




\begin{tabular}{|c|c|c|c|c|c|c|c|c|c|c|c|c|c|c|}
\hline VALID NAMES & NAMES CITED & $\begin{array}{l}\text { Reef. } \\
\text { Assoc. }\end{array}$ & GM & $\mathbf{I}$ & J & IEC & $\mathbf{T}$ & B & $\mathbf{C}$ & JP & SEC & $\mathbf{F}$ & IM & $\mathbf{U}$ \\
\hline Lutjanus apodus (Walbaum, 1792) & & $\mathrm{X}$ & 0 & 0 & 1 & 1 & 1 & 0 & 0 & 1 & 0 & 0 & 0 & 0 \\
\hline Lutjanus cyanopterus (Cuvier, 1828) & & $x$ & 1 & 0 & 1 & 0 & 0 & 0 & 0 & 0 & 0 & 1 & 0 & 0 \\
\hline Lutjanus griseus (Linnaeus, 1758) & & $\mathrm{X}$ & 0 & 0 & 1 & 1 & 0 & 0 & 0 & 0 & 0 & 1 & 0 & 0 \\
\hline Lutjanus jocu (Bloch \& Schneider, 1801) & & $\mathrm{X}$ & 1 & 0 & 1 & 1 & 1 & 0 & 0 & 0 & 0 & 1 & 1 & 0 \\
\hline Lutjanus synagris (Linnaeus, 1758) & & $\mathrm{X}$ & 1 & 1 & 1 & 1 & 1 & 0 & 0 & 0 & 1 & 1 & 0 & 0 \\
\hline Lycengraulis grossidens (Agassiz, 1829) & & & 1 & 1 & 1 & 1 & 0 & 0 & 0 & 0 & 1 & 1 & 1 & 0 \\
\hline Megalops atlanticus Valenciennes, 1847 & Tarpon atlanticus & $x$ & 0 & 0 & 1 & 1 & 0 & 0 & 0 & 0 & 0 & 1 & 0 & 0 \\
\hline Menticirrhus americanus (Linnaeus, 1758) & $\begin{array}{l}\text { Menticirrhus } \\
\text { martinicensis }\end{array}$ & $\mathrm{X}$ & 0 & 0 & 1 & 1 & 0 & 0 & 0 & 0 & 0 & 1 & 1 & 0 \\
\hline Microdesmus bahianus Dawson, 1973 & & & 0 & 0 & 0 & 0 & 0 & 0 & 0 & 0 & 0 & 1 & 0 & 0 \\
\hline $\begin{array}{l}\text { Microdesmus longipinnis (Weymouth, } \\
\text { 1910) }\end{array}$ & & & 0 & 0 & 0 & 0 & 0 & 0 & 1 & 1 & 0 & 1 & 0 & 0 \\
\hline $\begin{array}{l}\text { Microphis brachyurus lineatus (Kaup, } \\
\text { 1856) }\end{array}$ & Oostethus lineatus & $X$ & 0 & 1 & 1 & 0 & 0 & 0 & 0 & 0 & 0 & 0 & 1 & 1 \\
\hline
\end{tabular}




\begin{tabular}{|c|c|c|c|c|c|c|c|c|c|c|c|c|c|c|}
\hline VALID NAMES & NAMES CITED & $\begin{array}{l}\text { Reef. } \\
\text { Assoc. }\end{array}$ & $\mathbf{G M}$ & $\mathbf{I}$ & $\mathbf{J}$ & IEC & $\mathbf{T}$ & B & $\mathbf{C}$ & JP & SEC & $\mathbf{F}$ & IM & $\mathbf{U}$ \\
\hline Micropogonias furnieri (Desmarest, 1823) & & & 0 & 0 & 0 & 1 & 0 & 0 & 0 & 0 & 0 & 1 & 1 & 0 \\
\hline Mugil curema Valenciennes, 1836 & & $x$ & 1 & 0 & 1 & 1 & 0 & 1 & 0 & 1 & 0 & 1 & 0 & 0 \\
\hline Mugil liza Valenciennes, 1836 & Mugil brasiliensis & $x$ & 0 & 0 & 1 & 1 & 0 & 0 & 0 & 1 & 1 & 1 & 0 & 0 \\
\hline Mugil trichodon Poey, 1875 & & & 0 & 0 & 0 & 1 & 1 & 0 & 0 & 0 & 1 & 1 & 0 & 0 \\
\hline Mycteroperca bonaci (Poey, 1860) & & $X$ & 0 & 0 & 0 & 0 & 0 & 0 & 0 & 0 & 0 & 1 & 0 & 0 \\
\hline $\begin{array}{l}\text { Mycteroperca microlepis (Goode \& Bean, } \\
\text { 1879) }\end{array}$ & & $x$ & 0 & 0 & 0 & 1 & 0 & 0 & 0 & 0 & 0 & 0 & 0 & 0 \\
\hline Myrichthys ocellatus (Lesueur, 1825) & Myrichthys oculatus & $x$ & 0 & 0 & 0 & 0 & 0 & 0 & 0 & 0 & 1 & 0 & 0 & 0 \\
\hline Myrophis punctatus Lütken, 1852 & & $X$ & 0 & 0 & 1 & 0 & 0 & 0 & 0 & 0 & 0 & 0 & 0 & 0 \\
\hline Narcine brasiliensis (Olfers, 1831) & & $\mathrm{X}$ & 0 & 0 & 0 & 1 & 0 & 0 & 0 & 0 & 0 & 0 & 0 & 0 \\
\hline Ocyurus chrysurus (Bloch, 1791) & & $\mathrm{x}$ & 0 & 0 & 0 & 1 & 1 & 0 & 0 & 0 & 1 & 0 & 0 & 0 \\
\hline $\begin{array}{l}\text { Odontesthes bonariensis (Valenciennes, } \\
1835 \text { ) }\end{array}$ & & & 0 & 0 & 0 & 0 & 0 & 0 & 0 & 0 & 0 & 1 & 0 & 0 \\
\hline Ogcocephalus vespertilio (Linnaeus, 1758) & & $\mathrm{X}$ & 0 & 0 & 0 & 1 & 0 & 0 & 0 & 0 & 0 & 1 & 1 & 0 \\
\hline
\end{tabular}




\begin{tabular}{|c|c|c|c|c|c|c|c|c|c|c|c|c|c|c|}
\hline VALID NAMES & NAMES CITED & $\begin{array}{l}\text { Reef. } \\
\text { Assoc. }\end{array}$ & GM & $\mathbf{I}$ & $\mathbf{J}$ & IEC & $\mathbf{T}$ & B & $\mathbf{C}$ & JP & SEC & $\mathbf{F}$ & IM & $\mathbf{U}$ \\
\hline Oligoplites palometa (Cuvier, 1832) & & & 0 & 1 & 1 & 1 & 0 & 0 & 0 & 0 & 0 & 1 & 0 & 0 \\
\hline Oligoplites saliens (Bloch, 1793) & & & 0 & 0 & 0 & 1 & 0 & 0 & 0 & 0 & 0 & 0 & 0 & 0 \\
\hline $\begin{array}{l}\text { Oligoplites saurus (Bloch \& Schneider, } \\
\text { 1801) }\end{array}$ & & $\mathrm{X}$ & 1 & 1 & 1 & 1 & 1 & 0 & 0 & 0 & 1 & 1 & 0 & 0 \\
\hline Opisthonema oglinum (Lesueur, 1818) & & & 0 & 0 & 1 & 1 & 1 & 0 & 0 & 0 & 1 & 1 & 0 & 0 \\
\hline Orthopristis ruber (Cuvier, 1830) & & $x$ & 0 & 0 & 0 & 1 & 0 & 0 & 0 & 0 & 0 & 0 & 0 & 0 \\
\hline Paralichthys brasiliensis (Ranzani, 1842) & & $X$ & 0 & 0 & 0 & 1 & 0 & 0 & 0 & 0 & 0 & 1 & 0 & 0 \\
\hline $\begin{array}{l}\text { Paralichthys orbignyanus (Valenciennes, } \\
\text { 1839) }\end{array}$ & $\begin{array}{l}\text { Paralichthys } \\
\text { orbignyana }\end{array}$ & & 0 & 0 & 0 & 1 & 0 & 0 & 0 & 0 & 0 & 0 & 0 & 0 \\
\hline Paralichthys patagonicus Jordan, 1889 & $\begin{array}{l}\text { Paralichthys } \\
\text { bicyclophorus }\end{array}$ & & 0 & 0 & 0 & 1 & 0 & 0 & 0 & 0 & 0 & 0 & 0 & 0 \\
\hline Phtheirichthys lineatus (Menziens, 1791) & & & 0 & 0 & 0 & 0 & 0 & 0 & 0 & 0 & 0 & 1 & 0 & 0 \\
\hline Platanichthys platana (Regan, 1917) & & & 0 & 0 & 0 & 0 & 0 & 0 & 0 & 0 & 0 & 1 & 0 & 0 \\
\hline Poecilia vivipara Bloch \& Schneider, 1801 & & & 1 & 1 & 1 & 1 & 1 & 1 & 0 & 1 & 0 & 1 & 1 & 1 \\
\hline
\end{tabular}




\begin{tabular}{|c|c|c|c|c|c|c|c|c|c|c|c|c|c|c|}
\hline VALID NAMES & NAMES CITED & $\begin{array}{l}\text { Reef. } \\
\text { Assoc. }\end{array}$ & GM & $\mathbf{I}$ & $\mathbf{J}$ & IEC & $\mathbf{T}$ & B & $\mathbf{C}$ & JP & SEC & $\mathbf{F}$ & IM & $\mathbf{U}$ \\
\hline Polydactylus virginicus (Linnaeus, 1758) & & & 1 & 0 & 0 & 1 & 0 & 0 & 0 & 0 & 1 & 1 & 0 & 0 \\
\hline Pomacanthus paru (Bloch, 1787) & & $X$ & 0 & 0 & 0 & 1 & 0 & 0 & 0 & 0 & 0 & 0 & 0 & 0 \\
\hline $\begin{array}{l}\text { Pomadasys corvinaeformis (Steindachner, } \\
\text { 1868) }\end{array}$ & & $\mathrm{X}$ & 0 & 0 & 1 & 1 & 0 & 0 & 0 & 0 & 0 & 1 & 0 & 0 \\
\hline Pomadasys crocro (Cuvier, 1830) & & & 1 & 0 & 1 & 0 & 0 & 0 & 0 & 0 & 0 & 1 & 0 & 0 \\
\hline Pomadasys ramosus (Poey, 1860) & & & 1 & 0 & 1 & 0 & 0 & 0 & 0 & 0 & 0 & 0 & 0 & 0 \\
\hline Prionotus alipionis Teague \& Myers 1945 & Prionotus punctatus & & 0 & 0 & 1 & 1 & 0 & 0 & 0 & 0 & 1 & 1 & 0 & 0 \\
\hline Pseudupeneus maculatus (Bloch, 1793) & & $X$ & 0 & 0 & 0 & 1 & 0 & 0 & 0 & 0 & 1 & 1 & 0 & 0 \\
\hline $\begin{array}{l}\text { Rhinosardinia amazonica (Steindachner, } \\
\text { 1879) }\end{array}$ & & & 1 & 0 & 0 & 0 & 0 & 0 & 0 & 0 & 0 & 1 & 0 & 0 \\
\hline Rypticus randalli Courtenay, 1967 & & & 1 & 0 & 0 & 1 & 0 & 1 & 0 & 0 & 0 & 0 & 0 & 0 \\
\hline $\begin{array}{l}\text { Rypticus saponaceus (Bloch \& Schneider, } \\
\text { 1801) }\end{array}$ & & $x$ & 0 & 0 & 0 & 0 & 0 & 0 & 0 & 0 & 0 & 1 & 0 & 0 \\
\hline Scartella cristata (Linnaeus, 1758) & & $\mathrm{X}$ & 0 & 0 & 0 & 0 & 0 & 0 & 0 & 0 & 1 & 0 & 0 & 0 \\
\hline
\end{tabular}




\begin{tabular}{|c|c|c|c|c|c|c|c|c|c|c|c|c|c|c|}
\hline VALID NAMES & NAMES CITED & $\begin{array}{l}\text { Reef. } \\
\text { Assoc. }\end{array}$ & GM & $\mathbf{I}$ & J & IEC & $\mathbf{T}$ & B & $\mathbf{C}$ & JP & SEC & $\mathbf{F}$ & IM & $\mathbf{U}$ \\
\hline Scartella nuchifilis (Valenciennes, 1836) & Blennius cristatus & & 0 & 0 & 0 & 0 & 0 & 0 & 0 & 0 & 1 & 0 & 0 & 0 \\
\hline Sciades couma (Valenciennes, 1840) & Arius couma & & 1 & 0 & 0 & 0 & 0 & 0 & 0 & 0 & 0 & 0 & 0 & 0 \\
\hline Sciades herzbergii (Bloch, 1794) & Arius herzbergii & & 1 & 0 & 1 & 1 & 0 & 0 & 0 & 0 & 0 & 1 & 0 & 0 \\
\hline Sciades proops (Valenciennes, 1840) & $\begin{array}{l}\text { Hexanematichthys } \\
\text { proops; Arius proops }\end{array}$ & & 1 & 0 & 0 & 1 & 0 & 0 & 0 & 0 & 0 & 1 & 0 & 0 \\
\hline $\begin{array}{l}\text { Scomberomorus brasiliensis Collette, Russo } \\
\& \text { Zavala-Camin, } 1978 .\end{array}$ & & $X$ & 0 & 0 & 1 & 1 & 0 & 0 & 0 & 0 & 0 & 1 & 0 & 0 \\
\hline Scomberomorus cavalla (Cuvier, 1829) & & $X$ & 0 & 0 & 0 & 0 & 0 & 0 & 0 & 0 & 0 & 1 & 0 & 0 \\
\hline Scomberomorus maculatus (Mitchill, 1815) & & $X$ & 0 & 0 & 0 & 1 & 0 & 0 & 0 & 0 & 0 & 0 & 0 & 0 \\
\hline Scomberomorus regalis (Bloch, 1793) & & $X$ & 0 & 0 & 0 & 0 & 0 & 0 & 0 & 0 & 0 & 1 & 0 & 0 \\
\hline $\begin{array}{l}\text { Scorpaena isthmensis Meek \& Hildebrand, } \\
1928\end{array}$ & & & 0 & 0 & 0 & 0 & 0 & 0 & 0 & 0 & 0 & 1 & 0 & 0 \\
\hline Scorpaena plumieri Bloch, 1789 & & $X$ & 0 & 0 & 0 & 1 & 0 & 0 & 0 & 0 & 0 & 1 & 0 & 0 \\
\hline Selene setapinnis (Mitchill, 1815) & & & 0 & 0 & 0 & 1 & 0 & 0 & 0 & 0 & 0 & 0 & 0 & 0 \\
\hline
\end{tabular}




\begin{tabular}{|c|c|c|c|c|c|c|c|c|c|c|c|c|c|c|}
\hline VALID NAMES & NAMES CITED & $\begin{array}{l}\text { Reef. } \\
\text { Assoc. }\end{array}$ & $\mathbf{G M}$ & $\mathbf{I}$ & $\mathbf{J}$ & IEC & $\mathbf{T}$ & B & $\mathbf{C}$ & JP & SEC & $\mathbf{F}$ & IM & $\mathbf{U}$ \\
\hline Selene vomer (Linnaeus, 1758) & & $\mathrm{X}$ & 1 & 1 & 1 & 1 & 0 & 0 & 0 & 0 & 1 & 1 & 0 & 0 \\
\hline Sparisoma amplum (Ranzani, 1841) & Sparisoma viride & $X$ & 0 & 0 & 1 & 0 & 0 & 0 & 0 & 0 & 1 & 1 & 0 & 0 \\
\hline Sparisoma radians (Valenciennes, 1840) & & $x$ & 0 & 1 & 0 & 1 & 1 & 0 & 0 & 0 & 0 & 1 & 0 & 0 \\
\hline Sphoeroides greeleyi Gilbert, 1900 & & $x$ & 0 & 1 & 1 & 0 & 0 & 0 & 0 & 0 & 0 & 1 & 0 & 0 \\
\hline $\begin{array}{l}\text { Sphoeroides nephelus (Goode \& Bean, } \\
\text { 1882) }\end{array}$ & & $x$ & 0 & 0 & 0 & 0 & 0 & 0 & 0 & 0 & 0 & 1 & 0 & 0 \\
\hline Sphoeroides spengleri (Bloch, 1785) & & & 0 & 1 & 0 & 1 & 0 & 0 & 0 & 0 & 0 & 1 & 0 & 0 \\
\hline Sphoeroides testudineus (Linnaeus, 1758) & & & 1 & 1 & 1 & 1 & 1 & 0 & 0 & 1 & 1 & 1 & 1 & 0 \\
\hline Sphyraena barracuda (Edwards, 1771) & & $X$ & 1 & 1 & 1 & 1 & 0 & 0 & 0 & 0 & 1 & 1 & 0 & 0 \\
\hline Sphyraena guachancho Cuvier, 1829 & & $X$ & 0 & 0 & 0 & 0 & 0 & 0 & 0 & 0 & 0 & 1 & 0 & 0 \\
\hline Stegastes fuscus (Cuvier, 1830) & & $X$ & 0 & 0 & 0 & 0 & 0 & 0 & 0 & 0 & 0 & 1 & 0 & 0 \\
\hline Stegastes variabilis (Castelnau, 1855) & $\begin{array}{l}\text { Pomacentrus } \\
\text { variabilis; Eupomacen } \\
\text { trus variabis }\end{array}$ & $X$ & 0 & 0 & 0 & 1 & 0 & 0 & 0 & 0 & 1 & 0 & 0 & 0 \\
\hline
\end{tabular}




\begin{tabular}{|c|c|c|c|c|c|c|c|c|c|c|c|c|c|c|}
\hline VALID NAMES & NAMES CITED & $\begin{array}{l}\text { Reef. } \\
\text { Assoc. }\end{array}$ & GM & $\mathbf{I}$ & J & IEC & $\mathbf{T}$ & B & $\mathbf{C}$ & JP & SEC & $\mathbf{F}$ & IM & $\mathbf{U}$ \\
\hline $\begin{array}{l}\text { Steindachnerina elegans (Steindachner, } \\
\text { 1875) }\end{array}$ & $\begin{array}{l}\text { Pseudocurimata } \\
\text { elegans; Cumimata } \\
\text { elegans }\end{array}$ & & 0 & 0 & 0 & 0 & 0 & 0 & 0 & 0 & 0 & 0 & 0 & 1 \\
\hline Stellifer brasiliensis (Schultz, 1945) & & & 1 & 0 & 0 & 1 & 0 & 0 & 0 & 0 & 0 & 1 & 0 & 0 \\
\hline Stellifer microps (Steindachner, 1864) & Ophioscion microps & & 0 & 0 & 0 & 1 & 0 & 0 & 0 & 0 & 0 & 0 & 0 & 0 \\
\hline Stellifer rastrifer (Jordan, 1889) & & & 0 & 0 & 0 & 1 & 0 & 0 & 0 & 0 & 0 & 1 & 0 & 0 \\
\hline Strongylura marina (Walbaum, 1792) & & $X$ & 0 & 0 & 0 & 1 & 1 & 0 & 0 & 0 & 0 & 0 & 1 & 0 \\
\hline Strongylura timucu (Walbaum, 1792) & & $x$ & 1 & 1 & 1 & 1 & 0 & 0 & 0 & 0 & 0 & 1 & 0 & 0 \\
\hline Syacium micrurum Ranzani, 1842 & & $X$ & 0 & 0 & 0 & 1 & 1 & 0 & 0 & 0 & 0 & 0 & 0 & 0 \\
\hline $\begin{array}{l}\text { Symphurus plagusia (Bloch \& Schneider, } \\
1801 \text { ) }\end{array}$ & & & 1 & 0 & 1 & 1 & 1 & 0 & 0 & 1 & 0 & 1 & 1 & 0 \\
\hline $\begin{array}{l}\text { Symphurus tessellatus (Quoy \& Gaimard, } \\
1824 \text { ) }\end{array}$ & & & 1 & 0 & 0 & 0 & 0 & 0 & 0 & 0 & 0 & 1 & 0 & 0 \\
\hline Synbranchus marmoratus Bloch 1795 & & & 0 & 0 & 0 & 0 & 0 & 0 & 0 & 0 & 0 & 0 & 1 & 1 \\
\hline Syngnathus pelagicus Linnaeus, 1758. & Syngnathus rousseau & & 0 & 1 & 1 & 0 & 0 & 0 & 0 & 0 & 0 & 0 & 0 & 0 \\
\hline
\end{tabular}




\begin{tabular}{|c|c|c|c|c|c|c|c|c|c|c|c|c|c|c|}
\hline VALID NAMES & NAMES CITED & $\begin{array}{l}\text { Reef. } \\
\text { Assoc. }\end{array}$ & $\mathbf{G M}$ & $\mathbf{I}$ & J & IEC & $\mathbf{T}$ & B & $\mathbf{C}$ & JP & SEC & $\mathbf{F}$ & IM & $\mathbf{U}$ \\
\hline Synodus foetens (Linnaeus, 1766) & & $\mathrm{X}$ & 0 & 0 & 0 & 1 & 0 & 0 & 0 & 0 & 1 & 1 & 0 & 0 \\
\hline Synodus poeyi Jordan, 1887 & & & 0 & 0 & 0 & 1 & 0 & 0 & 0 & 0 & 0 & 0 & 0 & 0 \\
\hline Thalassophryne maculosa Günther, 1861 & & $\mathrm{X}$ & 0 & 0 & 0 & 1 & 0 & 0 & 0 & 0 & 0 & 0 & 0 & 0 \\
\hline Thalassophryne montevidensis (Berg, 1893) & & & 0 & 0 & 0 & 1 & 0 & 0 & 0 & 0 & 0 & 0 & 0 & 0 \\
\hline Thalassophryne nattereri Steindachner, 1876 & & & 1 & 1 & 1 & 1 & 0 & 0 & 0 & 0 & 0 & 1 & 1 & 0 \\
\hline Tomicodon fasciatus (Peters, 1859) & & & 0 & 0 & 0 & 1 & 0 & 0 & 0 & 0 & 0 & 0 & 0 & 0 \\
\hline Trachelyopterus galeatus (Linnaeus 1766) & $\begin{array}{l}\text { Trachycorystes } \\
\text { galeatus }\end{array}$ & & 0 & 0 & 0 & 0 & 0 & 0 & 0 & 0 & 0 & 0 & 0 & 1 \\
\hline Trachinotus carolinus (Linnaeus, 1766) & & $\mathrm{X}$ & 0 & 0 & 0 & 0 & 0 & 0 & 0 & 0 & 0 & 1 & 0 & 0 \\
\hline Trachinotus falcatus (Linnaeus, 1758) & & $\mathrm{x}$ & 0 & 0 & 0 & 1 & 0 & 0 & 0 & 0 & 1 & 1 & 0 & 0 \\
\hline Trichiurus lepturus Linnaeus, 1758 & & & 0 & 0 & 0 & 1 & 0 & 0 & 0 & 0 & 0 & 1 & 0 & 0 \\
\hline $\begin{array}{l}\text { Trinectes maculatus (Bloch \& Schneider, } \\
\text { 1801) }\end{array}$ & & & 0 & 0 & 0 & 1 & 0 & 0 & 0 & 0 & 0 & 0 & 1 & 0 \\
\hline Tylosurus acus (Lacepède, 1803) & & & 0 & 0 & 0 & 0 & 0 & 0 & 0 & 0 & 0 & 1 & 0 & 0 \\
\hline
\end{tabular}

